\title{
Composting leachate: characterization, treatment, and future perspectives
}

\author{
Dany Roy $\cdot$ Antonin Azaïs - Sanae Benkaraache $\cdot$ Patrick Drogui $(\mathbb{D} \cdot$ \\ Rajeshwar D. Tyagi
}

(C) Springer Science+Business Media B.V., part of Springer Nature 2018

\begin{abstract}
The increasing production of waste has led to one of the major environmental challenges of today: waste management. A solution to this problem is the composting of organic wastes. While the composting process transforms organic wastes into biologically stable compost, large amounts of highly contaminated leachates that present a direct risk to the environment are also produced. First off, this review discusses the origin and nature of contaminants found in composting leachates. In a general perspective, composting leachates are characterized by the presence of high concentrations of moderately biodegradable organic matter and nutrients and contain toxic pollutants such as heavy metals and plasticizers. Treatment technologies that have been studied are subsequently reported
\end{abstract}

and discussed (treatment efficiencies and operating costs). This review highlights the lack of available solutions to efficiently remove all contaminants found in these leachates, which is a major concern considering the increasing number of composting facilities. While both, membrane bioreactors and reverse osmosis, show promising results with $\mathrm{NH}_{4}, \mathrm{COD}$ and TSS removals of $>70,>85$ and $>99.9 \%$, respectively, the resulting effluent remains hazardous for the environment. Further studies are required to assess the use of a combination of biological and advanced oxidation process for the production of a safely disposable effluent.

D. Roy · A. Azaïs · S. Benkaraache · P. Drogui ( $₫)$.

R. D. Tyagi

INRS, 490, Rue de la Couronne, Québec, QC G1K 9A9,

Canada

e-mail: patrick.drogui@ete.inrs.ca 


\section{Graphical abstract}

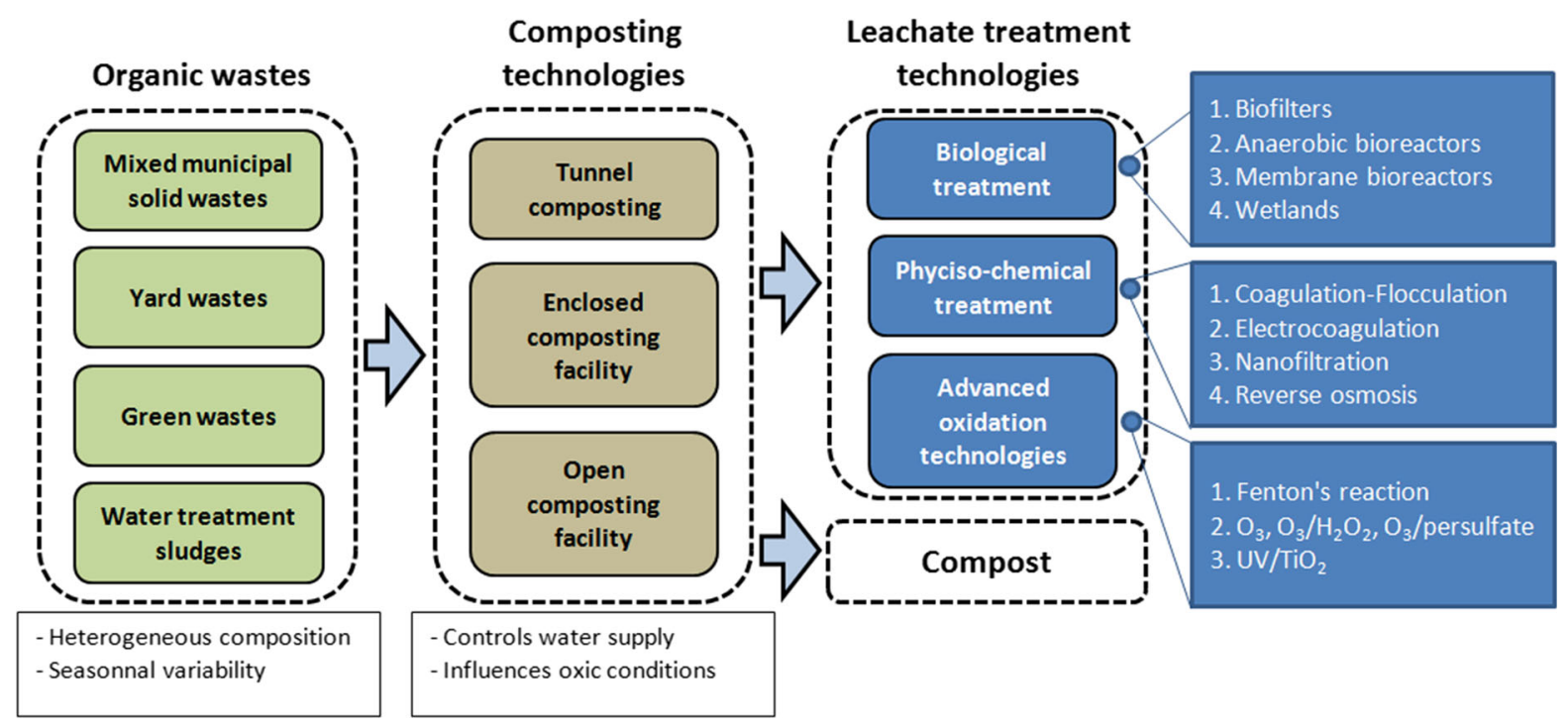

Keywords Composting leachate $\cdot$ Composting wastewater - Treatment - Membrane bioreactor . Advanced oxidation

\section{Introduction}

The exhaustive and exponential consumption of the growing human population has led us to one of the major environmental challenges that we face today: waste management. In 2007, the total amount of waste dumped across the globe was estimated at 2.12 billion tons (UNEP 2009).

Naturally, many different strategies have been proposed in order to attempt to counter and reduce the production of waste, such as composting. Composting technologies are an efficient manner of managing organic waste because they reduce the volume and weight of the initial waste by approximately 50\% (Haug 1993; He et al. 2011; GutiérrezMiceli et al. 2017). However, composting at the industrial scale generates large volumes leachates. While the compost itself can be reused as a beneficial soil amendment, composting leachates contain various hazardous substances that can have potential adverse effect on the environment, and that therefore need to be sufficiently treated prior to disposal (He et al. 2015; Mokhtarani et al. 2015).
Considering the growing efforts to find solutions to the increase in waste production, the number of composting facilities will most likely increase in the near future. Hence, larger volumes of leachate that needs to be treated will be produced. Research efforts in the field of composting leachate characterization and treatment have subsequently increased as well over the last few decades. Figure 1 illustrates the number of peer reviewed publications in the field of composting leachates since 1991. (Data bases: Google Scholar and Scopus, Keywords: composting leachate, compost leachate, leachate, treatment, organic waste).

Previously, a review has been published on the leachate originating from freshly applied compost in order to regulate the application of fresh compost as soil amendment (Chatterjee et al. 2013). Nonetheless, to the knowledge of the authors, no work has been previously done to summarize the studies conducted on the characterization and treatment of process wastewater originating from the composting process itself (composting leachates). Thus, the main purpose of this review paper is to summarize and discuss with a critical point of view the existing literature on the treatment of composting leachate. To begin, the typical composition of composting leachate is discussed, and the main factors effecting the composition are identified. Following this, the different technologies used for the treatment of composting leachate are outlined, and their efficacy in reducing the 


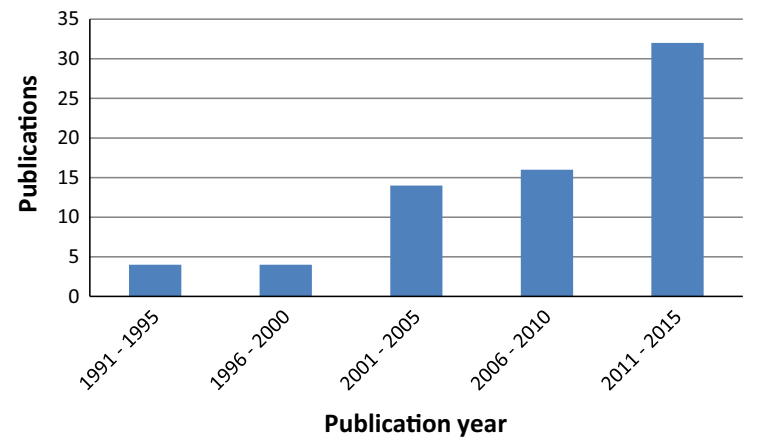

Fig. 1 Graphical representation of peer reviewed publications related to compost leachate since 1991

contamination levels is discussed. Furthermore, these technologies are also compared based on their operating costs. Finally, the future research perspectives in the field of composting leachate characterization, management, and treatment are presented.

\section{Composting leachate characterization}

\subsection{Composting leachate production} and contamination

Composting leachates originate from: (1) the water content of the organic waste itself (which represents approximately $60-90 \%$ content by weight), (2) the water generated during the composting biochemical reactions, (3) the rain water (open facilities), as well as (4) the water added in order to adjust the moisture content (Krogmann and Woyczechowski 2000). Leachate production is linked to the composting technology, the type of wastes composted, and the climatic conditions. Mixed municipal wastes generate approximately $75-100 \mathrm{~L} /$ ton of waste (Liu et al. 2010, 2015; Hashemi et al. 2017), green wastes produce between 5 and $50 \mathrm{~L} /$ ton of waste (Cakmakci and Ozyaka 2013; Bakhshoodeh et al. 2017), and sewage composting produces approximately 100 L/ton of sewage (Rajabi and Vafajoo 2012). Generally, composting facilities have the capacity to treat 1000-1500 ton/day of waste with reported leachate productions ranging from 4 to $400 \mathrm{~m}^{3} / \mathrm{d}$ (Liu et al. 2010; He et al. 2015; Bakhshoodeh et al. 2017).

Composting leachate contamination mainly occurs during the percolation of water (liquid phase) through the composting of organic waste.

Organic wastes are a major source of biodegradable organic matter, heavy metals, as well as emerging contaminants such as plasticizers (Fig. 2). The presence of a high content of organic matter in leachates results from the breakdown of large and complex organic matter into simpler substances by various microorganisms under aerobic conditions. Initially, (a)

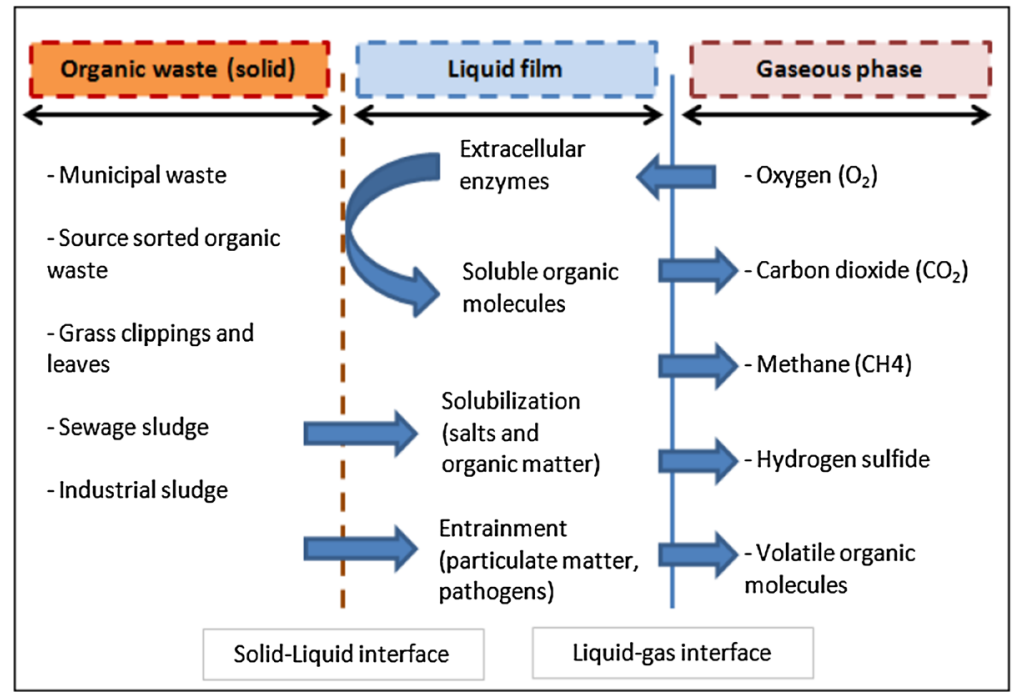

(b)

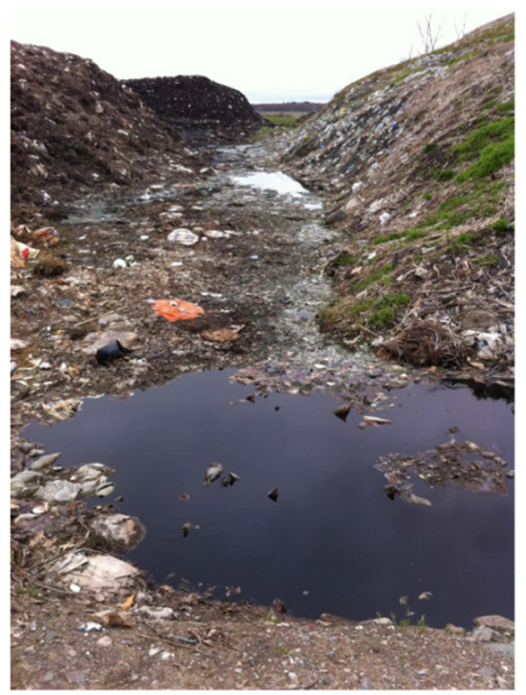

Fig. 2 a Schematic representation of the origin of composting leachate contamination, and b Composting leachate from an open composting facility 
microorganisms already present in the liquid phase surrounding the organic matter utilize the readily available dissolved biodegradable organic matter. Microorganisms simultaneously produce enzymes that react with solid organic matter to release soluble and readily available molecules in the biofilm. In addition to microbial activity, organic and inorganic matter (i.e. heavy metals) can be transferred to the liquid phase through solid-liquid mass transfer (de Guardia et al. 2002). Thus, the total mass transfer from biogenic waste to liquid phase can be divided into three different categories: (1) hydrolysis of biogenic waste through enzymatic reactions, (2) solubilization of organic and inorganic molecules and (3) entrainment of particulate matter (Krogmann and Woyczechowski 2000).

\subsection{Parameters influencing composting leachate composition}

\subsubsection{Feedstock}

The compost source material, i.e. the feedstock, determines to a large degree the composition of leachates. Major classes of feedstock suitable for composting have been summarized elsewhere (Chatterjee et al. 2013). Controlling the quality of raw organic waste fed into the composting process can limit the input of materials contaminated with undesired substances, those of which could potentially be found in the resulting composting leachate. Indeed, the presence of heavy metals in composting leachates has a strong correlation to the quality of the composted feedstock (Brown et al. 2013). However, their toxicity, bioavailability, and transport strongly depend on their physico-chemical forms (Bolea et al. 2010). Nutrients (organic and inorganic) concentrations in composting leachate are also influenced by feedstock composition. Several studies were conducted on nutrients availability in compost and results showed changes in chemical composition and biological availability over the course of composting process. Nevertheless, few have studied nutrient concentration in the leachate during the composting process (Amlinger et al. 2003). In addition to influencing the composition of leachates, composted material can also influence the amount of leachate produced. For example, when using wastewater to moisturize solid waste, an excess of substrate can lead to greater generation of leachates (Zahrim et al. 2015).

Seasonal variability of feedstock composition is also an important factor effecting leachate production and composition (Hashemi 2015). Gagnaire et al. (2012) observed leachate production varying from 2 to $14 \mathrm{~m}^{3} /$ day throughout the year due to differences in composted waste (such as water content) in the same composting facility (Gagnaire et al. 2012). GarcíaLópez et al. (2014) reported, for example, that total nitrogen can vary up to 2 times while copper can vary up to 75 times higher at their peak when compared to their lowest point, due to the seasonal variability of feedstock composition (García-López et al. 2014).

\subsubsection{Composting technology}

The composting technology affects the leachate composition in two different ways: (1) by controlling the water supply in the process, and (2) by influencing the oxic conditions in the composted waste. With tunnel composting technologies, compost is isolated from any external factors, and parameters such as moisture content, odor and aeration are well controlled (Kim et al. 2008). Enclosed and open composting facilities both process organic waste using mechanically-turned windrow (Sanchez-Monedero et al. 2003). In contrast to enclosed and tunnel composting facilities, the composition of composting leachate in an open composting facility is affected by climate conditions (Mullane et al. 2015).

In order to optimize the composting process and accelerate the biodegradation of organic waste, aerobic conditions must be maintained within the wastes. In tunnel composting, aerobic conditions are maintained through both frequent mechanical mixing as well as forced ventilation. However, in open composting facilities, aerobic conditions can only be obtained through mechanical mixing. Thus, open composting facilities operate alternately between aerobic and anaerobic conditions, resulting in a $\mathrm{pH}$ drop in leachates due to the rapid conversion of soluble organic molecules to volatile fatty acids (VFAs) in anaerobic conditions (Cho et al. 1995). The influence of the composting technology on composting leachate $\mathrm{pH}$ is highlighted in Table 1.

Low $\mathrm{pH}$ reported in open composting facility leachates can inhibit the biological nitrification process and make it difficult for biological treatment 
Table $1 \mathrm{pH}$ measurements in mixed municipal solid waste composting leachate originating from tunnel composting and open composting facilities

\begin{tabular}{llll}
\hline Composting technology & Authors & $\mathrm{pH}$ & Average pH \\
\hline Tunnel composting & Ozkaya (2005) & $6.8-7.2$ & $7.4 \pm 0.4$ \\
& Cakmakci and Ozyaka (2013) & $7.1-8.1$ & \\
& García-López et al. (2014) & $7.4-7.8$ & \\
& García-López et al. (2014) & $6.8-7.0$ & \\
& García-López et al. (2014) & $7.4-7.8$ & \\
& García-López et al. (2014) & $7.3-7.5$ & \\
& Romero et al. (2013) & 7,0 & \\
& Seyda Özyaka et al. (2015) & $7.1-8.1$ & \\
Open composting facility & Mokhtarani et al. (2012) & $4.2-6.8$ & $5.1 \pm 0.3$ \\
& Maleki et al. (2009) & $4.2-5.5$ & \\
& Elyasi, Amani et al. (2015) & $4.6-5.2$ & \\
& Zazouli and Yousefi (2008) & $4.3-5.9$ & \\
\hline
\end{tabular}

et al. 2013; Liu et al. 2015). Chemical oxygen demand (COD) is highly variable with reported values varying between 0.08 and $185 \mathrm{~g} \mathrm{O}_{2} / \mathrm{L}$. These high concentrations can potentially deplete the oxygen level in the receiving aquatic environment, causing the fatalities of plants, fish, and other aquatic organisms (Hashemi and Khodabakhshi 2016). The average COD concentration is significantly higher in the MSW leachates (48 $\mathrm{g} \mathrm{O}_{2} / \mathrm{L}$ ) than in the yard and green waste leachates ( $29 \mathrm{~g} \mathrm{O}_{2} / \mathrm{L}$ ). This difference can be explained by the lower biodegradability of the yard and green waste, which is caused by a high proportion of cellulosic biomass.

To assess the biodegradability of this organic contamination in the leachates, the $\mathrm{BOD}_{5} / \mathrm{COD}$ ratio is measured. A ratio above 0.5 is considered easily biodegradable and a ratio less than 0.1 is considered difficult to biodegrade (Krogmann and Woyczechowski 2000). The average $\mathrm{BOD}_{5} / \mathrm{COD}$ ratio of composting leachate is 0.33 , categorizing it as a moderately biodegradable wastewater (Henze et al. 2002). The composting process is characterized by both a disappearance of easily biodegradable compounds as well as an increase in aromatic character. Consequently, low biodegradability of organic matter in composting leachates can be explained by the size and nature of the organic matter in question. Mullane et al. (2015) found that humic- and fulvic-like substances with high molecular weight formed during composting are responsible for an important part of organic contamination in composting leachates (Mullane et al. 2015). He et al. (2015) reached the same conclusion by findings significant fluorescence peaks

Table 3 displays the composting leachates' nutrient concentrations (COD, BOD, nitrogen, and phosphorus) reported in the scientific literature. Nitrogen and organic matter are generally considered the two main contaminants found in composting leachates (Romero 


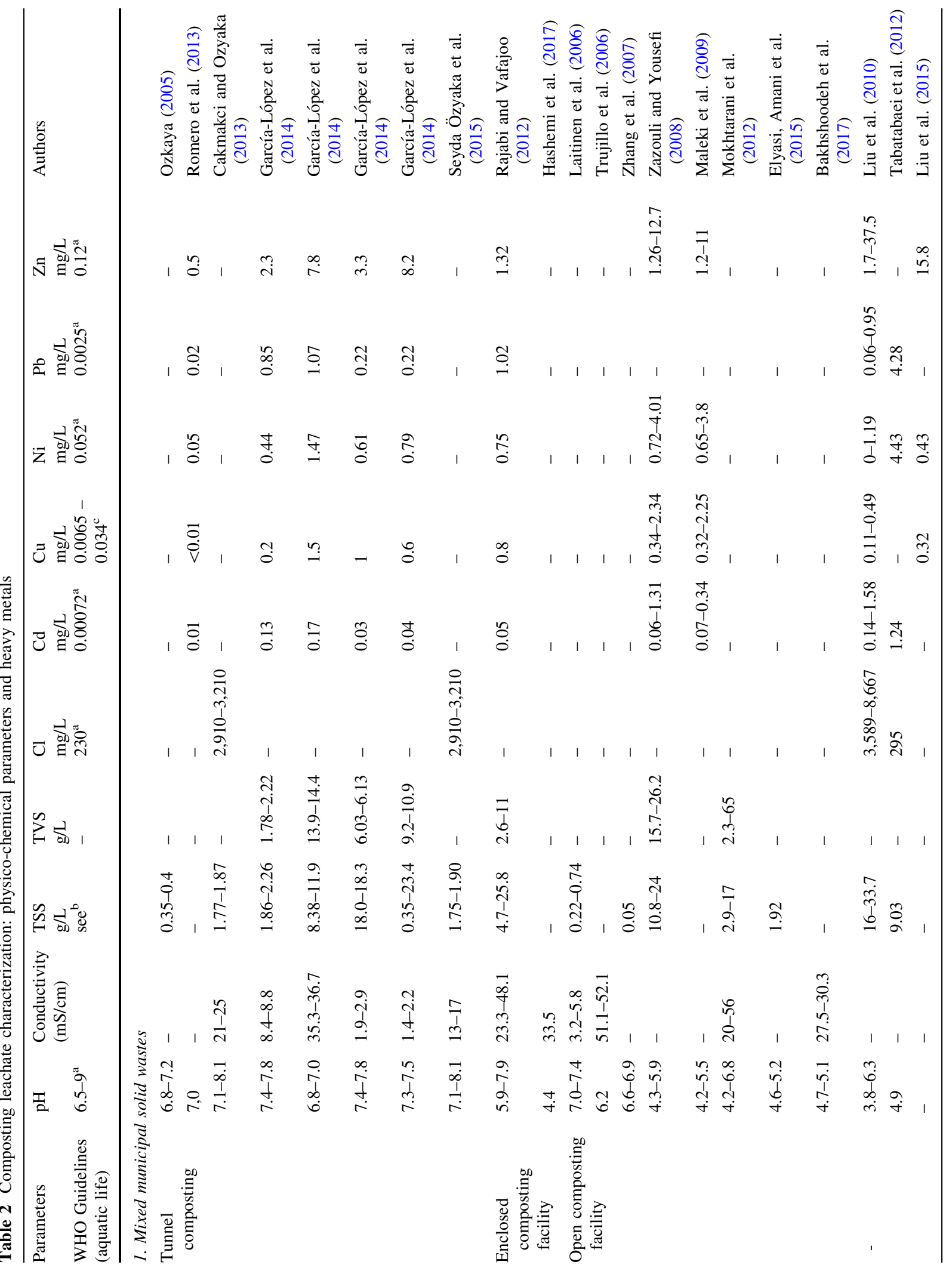




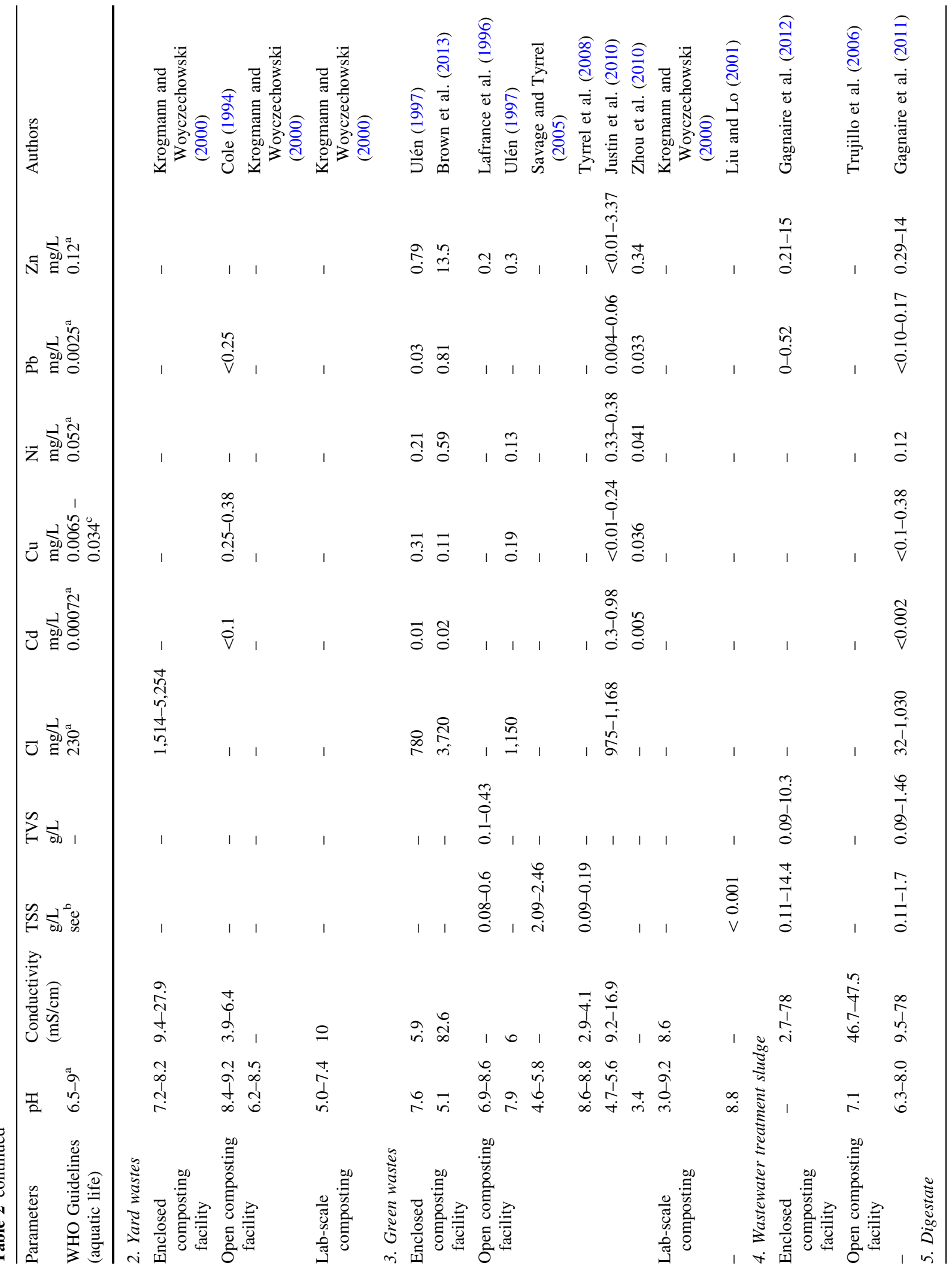




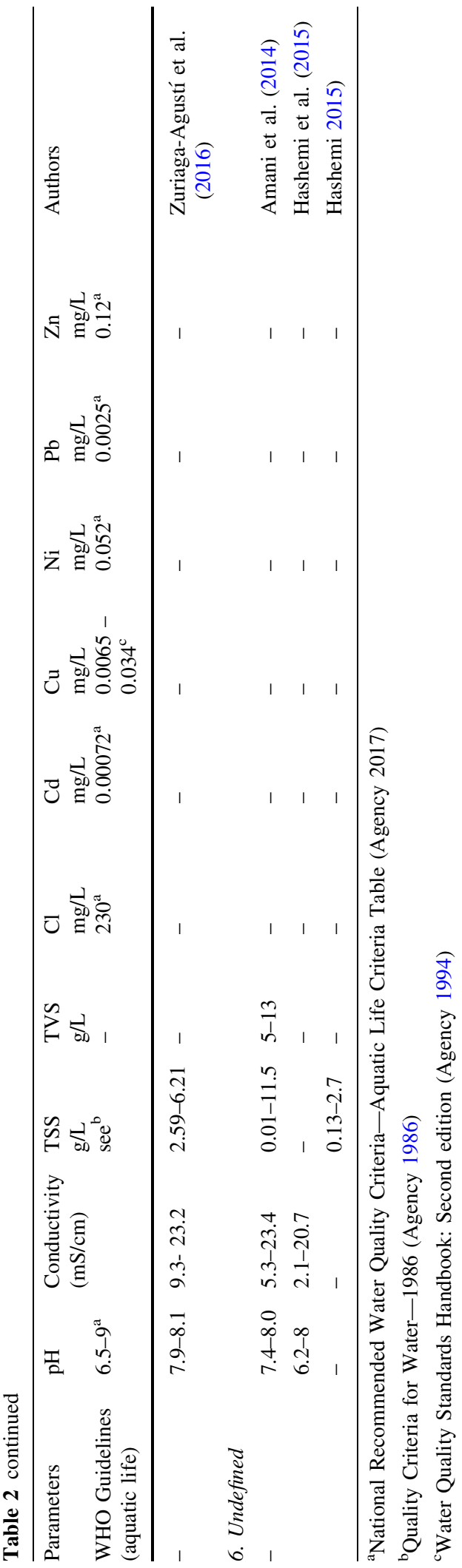

in the 300-380 and 380-500 $\mathrm{nm}$ regions, which corresponds to fulvic- and humic like substances, respectively (He et al. 2015). Generally, the molecular sizes of aquatic fulvic- and humic-acids are in the ranges 500-2000 and 2000-5000 Da, respectively (Nissinen et al. 2001). These organic molecules are known to play a significant role in both the organic matter's resistance to biodegradation, as well as heavy metal transport within the environment through complexation (He et al. 2011; Mullane et al. 2015).

Nitrogen leached during the microbial decay of organic matter is mainly found as dissolved organic nitrogen comprised of: (1) proteinaceous compounds and amines integrated into the fulvic- and humic-like substances and (2) ammonium salts(Popa and Green 2012; He et al. 2015). From Table 3, total Kjeldahl Nitrogen (TKN) concentrations measured in composting leachates range from 7.2 to $18570 \mathrm{mg} \mathrm{N} / \mathrm{L}$. The proportion of organic nitrogen found as ammonium $\left(\mathrm{NH}_{4} / \mathrm{NTK}\right.$ ratio) is $0.57 \pm 0.19 \mathrm{mg} \mathrm{N}-\mathrm{NH}_{4} / \mathrm{mg} \mathrm{N}_{\text {org }}$, which is comparable to domestic sewage in terms of bioavailability (Tas et al. 2009). US-EPA recommended TKN criteria for rivers and streams vary between 0.12 and $2.18 \mathrm{mg} \mathrm{N} / \mathrm{L}$, which is more than 1000 times lower than the concentrations found in composting leachates.

From Table 3, total phosphorus concentrations measured from different leachates range from 0.52 to $485 \mathrm{mg}$ $\mathrm{P} / \mathrm{L}$. This phosphorus mainly originates from the decomposition of easily biodegradable organic wastes such as MSW and green wastes. The highest phosphorus concentration was measured in a leachate originating from green wastes, composted in an enclosed facility (485 mg P/L) (Brown et al. 2013). While phosphorus does not pose any direct risk to aquatic life, an increased phosphorus concentration in aquatic environments incites the proliferation of algae and cyanobacteria, which in turn accelerates the eutrophication of aquatic environments. US-EPA recommended TP criteria for rivers and streams vary between 0.01 and $0.128 \mathrm{mg} \mathrm{P} / \mathrm{L}$, which is also more than 1000 times lower than average concentrations of composting leachates.

\subsubsection{Heavy metals}

Table 2 presents the composting leachates' heavy metal concentrations reported in the scientific literature. Average concentrations of the measured heavy metals are: $0.36 \mathrm{mg} \mathrm{Cd} / \mathrm{L}, 0.61 \mathrm{mg} \mathrm{Cu} / \mathrm{L}, 1.06 \mathrm{mg} \mathrm{Ni} /$ 
Table 3 Composting leachate characterization: nutrients and organic matter

\begin{tabular}{|c|c|c|c|c|c|c|c|c|}
\hline $\begin{array}{l}\text { WHO } \\
\text { Guideline } \\
\text { (aquatic life) }\end{array}$ & $\begin{array}{l}\mathrm{COD} \\
\mathrm{g} \mathrm{O}^{2} / \mathrm{L} \\
-\end{array}$ & $\begin{array}{l}\mathrm{BOD}_{5} \\
\mathrm{~g} \mathrm{O}^{2} / \mathrm{L} \\
-\end{array}$ & $\begin{array}{l}\mathrm{BOD}_{5} / \\
\mathrm{COD} \\
\text { ratio } \\
-\end{array}$ & $\begin{array}{l}\mathrm{TKN} \\
\mathrm{mg} \mathrm{N} / \mathrm{L} \\
0.12-2.18^{\mathrm{b}}\end{array}$ & 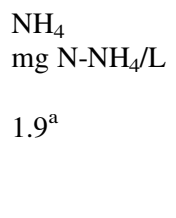 & $\begin{array}{l}0.01- \\
0.128^{\mathrm{b}}\end{array}$ & $\begin{array}{l}\mathrm{PO}_{4} \\
\mathrm{mg} \\
\mathrm{P}_{-} \mathrm{PO}_{4} / \mathrm{L} \\
-\end{array}$ & Authors \\
\hline \multicolumn{9}{|c|}{ 1. Mixed municipal solid wastes } \\
\hline \multirow{8}{*}{$\begin{array}{l}\text { Tunnel } \\
\text { composting }\end{array}$} & $8.5-9.0$ & - & - & $350-400$ & $250-300$ & - & $30-50$ & Ozkaya (2005) \\
\hline & $14.7-15.7$ & - & - & 1100 & $645-655$ & - & - & Romero et al. (2013) \\
\hline & $22.9-24.9$ & - & - & $1445-1545$ & $705-805$ & - & - & $\begin{array}{l}\text { Cakmakci and } \\
\text { Ozyaka (2013) }\end{array}$ \\
\hline & $10.6-12.6$ & $1.22-1.29$ & 0.11 & 1445 & $730-800$ & - & $81-85$ & $\begin{array}{l}\text { García-López et al. } \\
\text { (2014) }\end{array}$ \\
\hline & $38.8-42.8$ & $0.67-0.72$ & 0.02 & 2853 & $2,250-2275$ & - & $80-84$ & $\begin{array}{l}\text { García-López et al. } \\
\text { (2014) }\end{array}$ \\
\hline & $24.6-25.6$ & $7.59-7.90$ & 0.33 & 1612 & $950-1015$ & - & 87 & $\begin{array}{l}\text { García-López et al. } \\
\text { (2014) }\end{array}$ \\
\hline & $36.8-38.3$ & $5.70-5.93$ & 0.17 & 3213 & $1550-1625$ & - & 12 & $\begin{array}{l}\text { García-López et al. } \\
\text { (2014) }\end{array}$ \\
\hline & - & - & - & $1445-1545$ & - & - & - & $\begin{array}{l}\text { Seyda Özyaka et al. } \\
\text { (2015) }\end{array}$ \\
\hline \multirow{2}{*}{$\begin{array}{l}\text { Enclosed } \\
\text { composting } \\
\text { facility }\end{array}$} & $42.2-107.2$ & 40.1 & - & 758 & 520 & 0.52 & - & $\begin{array}{l}\text { Rajabi and Vafajoo } \\
\text { (2012) }\end{array}$ \\
\hline & 95.5 & 55.2 & 0.58 & 2,300 & - & 280 & - & $\begin{array}{l}\text { Hashemi et al. } \\
\text { (2017) }\end{array}$ \\
\hline \multirow{8}{*}{$\begin{array}{l}\text { Open } \\
\text { composting } \\
\text { facility }\end{array}$} & $1.97-2.43$ & $1.0-1.6$ & - & $160-320$ & $120-300$ & $8.2-13.4$ & $1.4-5.6$ & Laitinen et al. (2006) \\
\hline & $169-185$ & $85-89$ & 0.49 & - & - & - & - & Trujillo et al. (2006) \\
\hline & $25.8-45.5$ & - & - & - & - & - & - & $\begin{array}{l}\text { Zazouli and Yousefi } \\
\text { (2008) }\end{array}$ \\
\hline & $0.44-0.48$ & - & - & $43.6-49.2$ & $36-43$ & - & - & Zhang et al. (2007) \\
\hline & $22.3-45$ & - & - & - & - & - & - & Maleki et al. (2009) \\
\hline & $51-109$ & $23-55$ & $0.42-0.53$ & $467-1860$ & $258-1290$ & $32-193$ & - & $\begin{array}{l}\text { Mokhtarani et al. } \\
\text { (2012) }\end{array}$ \\
\hline & $23-40$ & - & - & - & - & - & - & $\begin{array}{l}\text { Elyasi, Amani et al. } \\
\text { (2015) }\end{array}$ \\
\hline & $102.8-107.9$ & $67.0-71.6$ & - & $5,820-6,660$ & $275-360$ & - & - & $\begin{array}{l}\text { Bakhshoodeh et al. } \\
\text { 2017) }\end{array}$ \\
\hline \multirow[t]{3}{*}{-} & $51.2-71.3$ & $26.2-30.4$ & - & $1,418-2,967$ & $231-796$ & $104-288$ & - & Liu et al. (2010) \\
\hline & 100 & - & - & - & - & - & - & $\begin{array}{l}\text { Tabatabaei et al. } \\
\text { (2012) }\end{array}$ \\
\hline & 55.7 & - & - & 10,056 & - & 71 & - & Liu et al. (2015) \\
\hline \multicolumn{9}{|l|}{ 2. Yard wastes } \\
\hline $\begin{array}{l}\text { Enclosed } \\
\text { composting } \\
\text { facility }\end{array}$ & $2.43-31.8$ & $0.008-11.6$ & - & - & $98-558$ & - & - & $\begin{array}{l}\text { Krogmann and } \\
\text { Woyczechowski } \\
(2000)\end{array}$ \\
\hline $\begin{array}{l}\text { Open } \\
\text { composting } \\
\text { facility }\end{array}$ & - & - & - & - & $5.1-10.5$ & - & - & Cole (1994) \\
\hline $\begin{array}{l}\text { Lab-scale } \\
\text { composting }\end{array}$ & 0.08 & 0.03 & 0.22 & 7.2 & 1.3 & - & - & $\begin{array}{l}\text { Krogmann and } \\
\text { Woyczechowski } \\
(2000)\end{array}$ \\
\hline
\end{tabular}


Table 3 continued

\begin{tabular}{|c|c|c|c|c|c|c|c|c|}
\hline $\begin{array}{l}\text { WHO } \\
\text { Guideline } \\
\text { (aquatic life) }\end{array}$ & $\begin{array}{l}\mathrm{COD} \\
\mathrm{g} \mathrm{O}^{2} / \mathrm{L}\end{array}$ & $\begin{array}{l}\mathrm{BOD}_{5} \\
\mathrm{~g} \mathrm{O}^{2} / \mathrm{L} \\
-\end{array}$ & $\begin{array}{l}\mathrm{BOD}_{5} / \\
\mathrm{COD} \\
\text { ratio } \\
-\end{array}$ & $\begin{array}{l}\text { TKN } \\
\mathrm{mg} \mathrm{N} / \mathrm{L} \\
0.12-2.18^{\mathrm{b}}\end{array}$ & $\begin{array}{l}\mathrm{NH}_{4} \\
\mathrm{mg} \mathrm{N}^{-\mathrm{NH}_{4}} / \mathrm{L} \\
1.9^{\mathrm{a}}\end{array}$ & $\begin{array}{l}\mathrm{TP} \\
\mathrm{mg} / \mathrm{L} \\
0.01- \\
0.128^{\mathrm{b}}\end{array}$ & $\begin{array}{l}\mathrm{PO}_{4} \\
\mathrm{mg} \\
\mathrm{P}-\mathrm{PO}_{4} / \mathrm{L} \\
-\end{array}$ & Authors \\
\hline \multicolumn{9}{|c|}{ 3. Green wastes } \\
\hline \multirow{2}{*}{$\begin{array}{l}\text { Enclosed } \\
\text { composting } \\
\text { facility }\end{array}$} & - & - & - & 240 & - & 28 & - & Ulén (1997) \\
\hline & 116 & - & - & - & 2720 & 485 & - & Brown et al. (2013) \\
\hline \multirow{6}{*}{$\begin{array}{l}\text { Open } \\
\text { composting } \\
\text { facility }\end{array}$} & $0.85-10$ & $0.15-5.4$ & $0.18-0.87$ & $40-150$ & $4-71$ & $28-35$ & - & $\begin{array}{l}\text { Lafrance et al. } \\
\text { (1996) }\end{array}$ \\
\hline & - & - & - & 420 & - & 16 & - & Ulén (1997) \\
\hline & - & $44.7-52.8$ & - & - & - & - & - & $\begin{array}{l}\text { Savage and Tyrrel } \\
\text { (2005) }\end{array}$ \\
\hline & $0.53-1.15$ & $0.02-0.26$ & $0.03-0.25$ & - & $6.5-24.1$ & $1.5-2.4$ & - & Tyrrel et al. (2008) \\
\hline & - & - & - & $970-1105$ & $887-980$ & $46-372$ & $15-119$ & Justin et al. (2010) \\
\hline & 75.7 & - & - & - & 824 & - & - & Zhou et al. (2010) \\
\hline $\begin{array}{l}\text { Lab-scale } \\
\text { composting }\end{array}$ & 0.29 & 0.06 & 0.26 & 250 & 107 & - & - & $\begin{array}{l}\text { Krogmann and } \\
\text { Woyczechowski } \\
(2000)\end{array}$ \\
\hline \multirow[t]{2}{*}{-} & $18-68$ & $10-46$ & $0.55-0.67$ & - & $400-1,100$ & - & - & $\begin{array}{l}\text { Krogmann and } \\
\text { Woyczechowski } \\
(2000)\end{array}$ \\
\hline & 0.98 & 0.1 & 0.11 & - & - & - & - & Liu and Lo (2001) \\
\hline \multicolumn{9}{|c|}{ 4. Wastewater treatment sludge } \\
\hline $\begin{array}{l}\text { Enclosed } \\
\text { composting } \\
\text { facility }\end{array}$ & $1.46-43.4$ & $0.36-17.4$ & $0.2-0.59$ & $345-18,570$ & $218-21,180$ & $7-88$ & - & $\begin{array}{l}\text { Gagnaire et al. } \\
\text { (2012) }\end{array}$ \\
\hline $\begin{array}{l}\text { Open } \\
\text { composting } \\
\text { facility }\end{array}$ & $126-140$ & $70-72$ & 0.54 & - & - & - & - & Trujillo et al. (2006) \\
\hline- & $1.88-42.4$ & $1.6-17.4$ & $0.32-0.55$ & $1470-7960$ & $1167-21,180$ & $22-78$ & - & $\begin{array}{l}\text { Gagnaire et al. } \\
\text { (2011) }\end{array}$ \\
\hline \multicolumn{9}{|l|}{ 5. Digestate } \\
\hline- & $1.88-4.40$ & - & - & $470-1110$ & 443-1091 & - & - & $\begin{array}{l}\text { Zuriaga-Agustí et al. } \\
\text { (2016) }\end{array}$ \\
\hline \multicolumn{9}{|l|}{ 6. Undefined } \\
\hline \multirow[t]{3}{*}{-} & $83-107$ & - & $0.2-0.3$ & - & - & - & - & Amani et al. (2014) \\
\hline & $0.42-7.25$ & $0.07-2.3$ & $0.28-0.38$ & - & - & - & - & $\begin{array}{l}\text { Hashemi et al. } \\
\text { (2015) }\end{array}$ \\
\hline & $0.085-5.36$ & $0.1-0.5$ & - & - & - & - & - & Hashemi (2015) \\
\hline
\end{tabular}

${ }^{a}$ National Recommended Water Quality Criteria-Aquatic Life Criteria Table (Agency 2017)

${ }^{\mathrm{b}}$ Summary Table for the Nutrient Criteria Documents (Agency 2014)

$\mathrm{L}, 0.64 \mathrm{mg} \mathrm{Pb} / \mathrm{L}$ and $6.93 \mathrm{mg} \mathrm{Zn} / \mathrm{L}$. The highest concentrations for each of these metals were found in the leachates originating from MSW composted in open composting facilities (Table 2) due to the low $\mathrm{pH}$ caused by anoxic conditions within the organic wastes which increases the mobility of the heavy metals contained in the miscellaneous wastes from the MSW.

When compared to the NRWQC criteria for freshwater aquatic life, each metal has a concentration 
of at least ten times higher that of the recommended concentration. To assess the bioavailability and mobility in natural environments, metal complexation with organic matter in composting leachates has been studied. He et al. (2015) observed that Ni exhibited a strong complexation capability with aliphatic structures, carbohydrates and proteinaceous compounds, although there was no significant complexation between proteinaceous compounds and amine with $\mathrm{Cu}, \mathrm{Cd}$ and $\mathrm{Zn}$ (He et al. 2015). Weng et al. (2002) showed that $\mathrm{Cu}$ and $\mathrm{Pb}$ have higher tendencies to form complexes with natural organic matter than do $\mathrm{Cd}, \mathrm{Zn}$ and $\mathrm{Ni}$ (Weng et al. 2002). Metal binding to organic matter in composting leachates can affect the solubility of metals to a considerable extent. The formation of organometallic complexes, combined with low $\mathrm{pH}$ leachates and the presence of large humic- and fulviclike molecules, can explain the high concentrations of heavy metals found in composting leachates.

\subsubsection{Dissolved and suspended solids}

Dissolved and suspended solid concentrations in composting leachates are presented in Table 2. The conductivity measurements in composting leachates range from 1420 to $82600 \mu \mathrm{S} / \mathrm{cm}$. For comparison, the typical conductivity of potable freshwater and seawater are estimated at $30-1500 \mu \mathrm{S} / \mathrm{cm}$ and $53,000 \mu \mathrm{S} / \mathrm{cm}$, respectively (Assiry et al. 2010, Fondriest Environmental 2014). Instead of regulating the conductivity, the NRWQC sets a chloride concentration criterion at $230 \mathrm{mg} / \mathrm{L}$ for freshwater aquatic life. Chloride concentrations measured in composting leachates range from 32 to $8667 \mathrm{mg} / \mathrm{L}$ (Table 2). Thus, chloride in composting leachate can reach concentrations ten times higher than the criterion. Concentration of total suspended solids (TSS) in composting leachates is also highly variable (86-33 $680 \mathrm{mg} / \mathrm{L}$ ). This variability can be caused by the leachate collection system (residence time, turbulence) and the particle size. However, this particular information has not been discussed in any of the studies. In comparison to municipal wastewater TSS concentrations, which generally varies between 100 and $350 \mathrm{mg} / \mathrm{L}$ with an average of $220 \mathrm{mg} / \mathrm{L}$, composting leachate TSS concentration is very high and is likely to cause a decrease of light availability which can reduce photosynthetic rates, leading to adverse effects on algae and macrophytes (Quinteiro et al. 2015).

\subsubsection{Toxic organic pollutants}

With the increase in number of composting facilities, as well as the variety of composted wastes, the presence of toxic organic pollutants (TOPs) in composting leachates is worth paying attention to (Kuster et al. 2008; Lonappan et al. 2016). Research conducted by Marttinen et al. (2004) and Fromme et al. (2002) have evidenced the presence of phtalates (a common plasticizer) in composting leachates (Fromme et al. 2002; Marttinen et al. 2004). Fromme et al. (2002) reported concentrations of 17-26 $\mu \mathrm{g}$ DEHP/L and 25-146 $\mu \mathrm{g}$ $\mathrm{BPA} / \mathrm{L}$ in mixed municipal-solid wastes composting leachates. These plasiticizers may originate from the plastic bags in which organic wastes are collected. Marttinen et al. (2004) reported concentrations of 9-34 $\mu \mathrm{g}$ DEHP/L in municipal sewage sludge composting leachates (Marttinen et al. 2004). Bis-phenol A (BPA) and polycyclic aromatic hydrocarbons (PAHs), such as pyrene, have also been detected in composting leachates (Zhang et al. 2007; Hashemi et al. 2016a, b).

Due to the significant number of sources from which TOPs can be introduced into the composting process, the possible leachate TOPs contamination should be considered when assessing leachate treatments.

\section{Composting leachate management and treatment}

\subsection{Reducing leachate generation}

The least expensive option for leachate management is to design the composting facility in such a way that reduces and reuses all excess water, meaning that leachate treatment is only needed as a last resort. In order to prevent leachate production, the facility should be designed to separate rainfall and snowmelt from organic wastes and compost. Then, a proper mix of compost feedstocks should be used; this ideal mix of compost feedstocks includes neither using materials that are too wet nor adding to much water to the mixture. To reach this objective, the moisture content of the compost should never exceed 65\% (Forgie et al. 2004). 
Similarly to bioreactor landfill, leachates generated during the composting process can be reintroduced in the compost windrow to provide humidity control and process optimization. Bilgili et al. (2007) studied the effect of recirculating leachates in lysimeter filled with MSW. Recirculating leachates reduced the total amount of leachate produced by $47.1 \%$, and reduced the initial concentration of COD $\left(40 \mathrm{~g} \mathrm{O}_{2} / \mathrm{L}\right)$ by $93 \%$ (Bilgili et al. 2007). Thus, recirculating the composting leachates both reduces the volume and the charge of organic contaminants to be treated, as well as improves the composting process (Ming et al. 2008).

Excess leachates that cannot be reused must be treated up to a standard that does not impact the environment. Different treatment technologies have been developed or specifically adapted for the treatment of composting leachates. In order to discuss their efficacy in reducing composting leachate contamination, these technologies have been separated into three different categories: (1) Biological treatment, (2) Physico-chemical treatment, and (3) Advanced technologies. Furthermore, the potential reuse or transformation of composting leachate, as well as the strategies to reduce the amount of leachates produced, are also discussed.

\subsection{Biological treatment}

The lower operating costs and simple operation of biological wastewater treatment technologies, compared to the physico-chemical and advanced treatment technologies, makes biological treatment technologies attractive for composting facilities that need low-cost options for leachate treatment. However, despite these advantages, biological treatments are known to require extensive hydraulic retention time (HRT $>48 \mathrm{~h}$ ), and to produce large amounts of sludge that need to be disposed off. The selection of appropriate biological treatment is based on the $\mathrm{C}_{\mathrm{BOD} 5} / \mathrm{N} / \mathrm{P}$ ratio. For a of $100 / 5 / 1$ ratio, an aerobic biological treatment is generally recommended (Lafrance et al. 1996). For 250 to $500 / 5 / 1$ ratio, an anaerobic treatment/digestion is generally recommended (Mokhtarani et al. 2012). Calculated from Table 3 , the average $\mathrm{C}_{\mathrm{DBO}} / \mathrm{N} / \mathrm{P}$ ratio in composting leachate is $320 / 30 / 1$. Thus, the $\mathrm{C} / \mathrm{P}$ ratio of composting leachates fulfills the requirements for anaerobic treatment while the $\mathrm{C} / \mathrm{N}$ ratio fulfill those for an aerobic treatment. The treatment efficacies of the different biotreatment technologies applied to composting leachates are summarized in Table 4.

\subsubsection{Biofilters}

Biofilters are packed-bed reactors filled with different media in which composting leachate is percolated. The media both acts as a support for microbial growth and increases the contact surface area between the biofilm and the leachates. A preliminary study was conducted by Lafrance et al. (1996) using mature compost, peat and vermiculite as media. The best results were obtained with a 35/35/30 mixture of peat, mature compost and vermiculite (Lafrance et al. 1996). Using this mixture, they removed $95 \%$ of $\mathrm{BOD}_{5}, 48 \%$ of COD, and $57 \%$ of ammoniacal nitrogen. Subsequently, Savage and Tyrrel (2005) conducted a laboratory study using six different packing materials: polystyrene, soil, broken bricks, mature compost, oversize (woody waste produced in the final screening of compost), and wood mulch (Savage and Tyrrel 2005). The best results were obtained with the oversize media with a $\mathrm{BOD}_{5}$ and ammoniacal nitrogen average removal of $78 \%$. Both studies concluded that biofilters made a significant impact on composting leachate quality, however, the filtrate remained highly polluted and required further treatment (Lafrance et al. 1996; Savage and Tyrrel 2005).

Following these lab-scale studies, Tyrrel et al. (2008) conducted a pilot scale study using two types of filter media, mature compost and oversize. Applying hydraulic loading rates ranging from 0.05 to $0.5 \mathrm{~m}^{3} /$ $\mathrm{m}^{3}$ (media)/day, they produced an effluent with $<10 \mathrm{mg} / \mathrm{L}$ ammoniacal nitrogen on $>95 \%$ of sampling occasions (initial concentrations of ammoniacal nitrogen ranged from 6.5 to $32 \mathrm{mg} / \mathrm{L}$ ) with the oversize media. However, they obtained low COD removal results (Tyrrel et al. 2008).

In general, biofilters with oversize material as a media are an efficient treatment technology for $\mathrm{NH}_{3}$ removal. The advantage of this technology is that is reuses available residues that have no/low-cost for composting facilities. However, hydraulic loading rates are low, meaning that the size of such a system would be exceedingly large for large scale composting facilities. Furthermore, COD removals are deficient, meaning that further treatments would be needed. A 


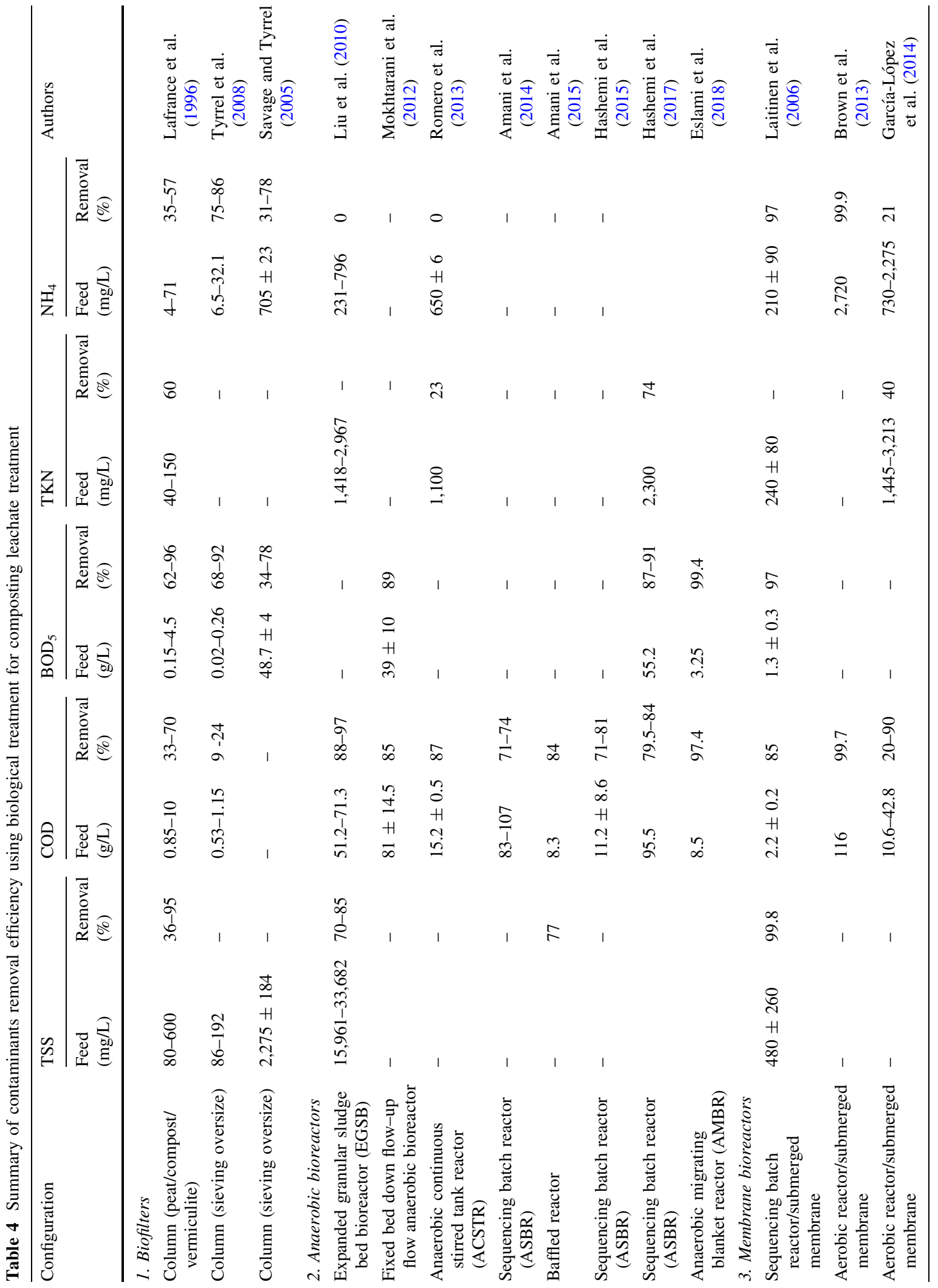




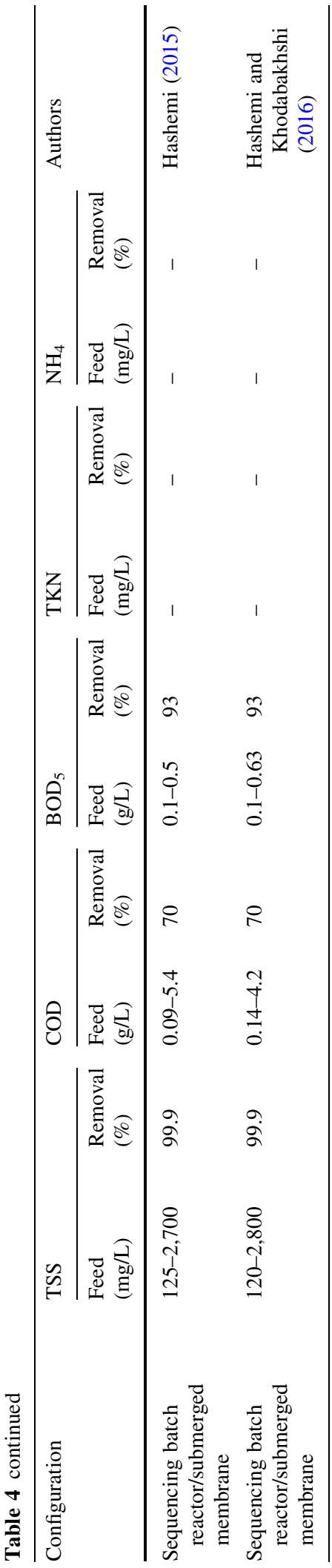

summary of the treatment efficacies of biofilters is presented in Table 4.

\subsubsection{Anaerobic bioreactors}

Anaerobic bioreactors (AB) are an assembly of processes involving biological decomposition of organic matter under anaerobic conditions. Anaerobic digestion has attracted increasing attention, mainly due to its considerable benefits such as usable biogas, high refractory COD treatment efficiency and low sludge production (Elyasi, Amani et al. 2015). Studies on composting leachate treatment have reported the use of both simple anaerobic systems (anaerobic continuous stirred tank reactor (A-CSTR) (Romero et al. 2013), anaerobic baffled reactor (Elyasi, Amani et al. 2015) and anaerobic sequencing batch reactor (ASBR) (Amani et al. 2014; Hashemi et al. 2015, 2017)), as well as more complex anaerobic systems (expanded granular sludge bed bioreactor (EGSB) (Liu et al. 2010), anaerobic migrating blanket reactor (AMBR) (Hashemi et al. 2016a, b; Eslami et al. 2018) and fixed bed down flow-up flow anaerobic bioreactor (Mokhtarani et al. 2012). Treatment efficiencies of these bioprocesses are summarized in Table 4.

$\mathrm{COD}$ removals using $\mathrm{AB}$ vary between 71 and $99.4 \%$, with the anaerobic migrating blanket reactor having the highest removal rates reported (82.4-97.5\% (Liu et al. 2010; Eslami et al. 2018). Mokhtarani et al. (2012) studied the effect of different OLRs on COD removal efficiency, and found that COD removal efficiency was independent of OLR below a value of $6 \mathrm{~kg} \mathrm{COD} / \mathrm{m}^{3} /$ day. Above that OLR, the COD removal efficiency was significantly reduced (Mokhtarani et al. 2012). However, these findings disagree with those of Liu et al. (2010), who found that an OLR of $22.5 \pm 1.5 \mathrm{~kg} \mathrm{COD} / \mathrm{m}^{3} /$ day was optimal. While both organic contaminations have similar $\mathrm{BOD}_{5} / \mathrm{COD}$ ratios (ranging from 0.42 to 0.53 ), potential explanations for the discrepancy between their conclusions include different Food/Microorganisms $(\mathrm{F} / \mathrm{M})$ ratios which were not discussed.

Mokhtarani et al. (2012) observed that although nutrient concentrations in their raw leachate $(\mathrm{C} / \mathrm{N} /$ $\mathrm{P}=350 / 4 / 0.4$ ) were low, they had no significant effect on the COD removal efficiency and performance of the reactors (Mokhtarani et al. 2012). This particularity of biological treatment is interesting for 
Table 5 Biogas production potential of composting leachates

\begin{tabular}{|c|c|c|c|c|c|}
\hline Anaerobic bioreactor technology & $\begin{array}{l}\mathrm{BOD}_{5} / \mathrm{COD} \\
\text { ratio }\end{array}$ & $\begin{array}{l}\text { Yield } \\
\text { (L biogas/g } \\
\text { COD) }\end{array}$ & $\begin{array}{l}\text { Biogas } \\
\text { quality } \\
\text { (\% methane) }\end{array}$ & $\begin{array}{l}\text { Conversion } \\
\text { (\% COD) }\end{array}$ & Authors \\
\hline $\begin{array}{l}\text { Expanded granular sludge bed bioreactor } \\
\text { (EGSB) }\end{array}$ & $0.43-0.51$ & $0.23-0.29$ & $60-80$ & $80-83$ & Liu et al. (2010) \\
\hline Anaerobic sequencing batch reactor (ASBR) & $0.2-0.3$ & $0.5-0.52$ & 75 & - & Amani et al. (2014) \\
\hline Anaerobic sequencing batch reactor (ASBR) & $0.28-0.38$ & 0.36 & $55-65$ & 85 & $\begin{array}{l}\text { Hashemi et al. } \\
\text { (2015) }\end{array}$ \\
\hline $\begin{array}{l}\text { Anaerobic migrating blanket reactor } \\
\text { (AMBR) }\end{array}$ & 0.38 & 0.34 & - & - & Eslami et al. (2018) \\
\hline
\end{tabular}

wastewaters with variable composition, such as composting leachates.

Hashemi et al. (2016a, b) studied the removal of PAHs and heavy metals using an anaerobic migrating blanket reactor. With OLR ranging from 1 to $19.7 \mathrm{~g}$ $\mathrm{COD} / \mathrm{L} /$ day, they obtained an average removal efficiency of $73 \%$ for the PAHs. In terms of the heavy metals ( $\mathrm{Ni}, \mathrm{Zn}, \mathrm{Cr}, \mathrm{Cd}, \mathrm{Pb}, \mathrm{Cu}$ ), the AMBR process reduced their concentrations by $42-55 \%$ (Hashemi et al. 2016a, b).

Conversion potential of the organic contamination to biogas has also been studied (Liu et al. 2010, Amani et al. 2014, Hashemi et al. 2015, Eslami et al. 2018). The yield and the quality of biogas produced are presented in Table 5.

Conversion rates are considered high, with reported values of $80-85 \%$, despite the low biodegradability of organic contamination $\left(\mathrm{BOD}_{5} / \mathrm{COD}=0.28-0.38\right)$. The methane content of biogas originating from the anaerobic digestion of composting leachate is comparable to the anaerobic digestion of household wastes (50-60\%) and agricultural wastes (60-75\%). Using an AMBR, Eslami et al. (2018) showed that the optimal production of biogas is obtained with an OLR of $10 \mathrm{~g}$ $\mathrm{COD} \times \mathrm{L}^{-1} \times \mathrm{day}^{-1}$. Higher OLRs lead to a sudden decrease in biogas production due to the accumulation of VFAs that become harmful for methanogenic Achaea bacteria (Eslami et al. 2018). Whereas studies have proven that $\mathrm{AB}$ is efficient for $\mathrm{COD}$ removal, this process is not as efficient for ammoniacal nitrogen contamination. Liu et al. (2010) noted that ammoniacal nitrogen concentration in the effluent was $150-400 \mathrm{mg} / \mathrm{L}$ higher than in the influent. Their explanation was that proteins in the influent are biodegraded and some nitrogen is converted in the form of $\mathrm{NH}_{3}$ (Liu et al. 2010). This finding is further supported by Romero et al. (2013), who also observed an increase in ammoniacal nitrogen concentration after the anaerobic digestion of raw leachates (Romero et al. 2013). Thus, the presence of refractory COD, TSS, high turbidity, and high concentrations of ammoniacal nitrogen in anaerobic reactor effluents confirms the necessity of other techniques as posttreatments.

\subsubsection{Membrane bioreactors}

An alternative technology to anaerobic bioreactors, known for its high COD removal efficiency, its small foot print and its capacity of treating wastewater with lower biodegradability, is the membrane bioreactor (MBR). MBRs are wastewater treatment processes that integrate a permselective membrane with a biological process (Judd 2010). The membrane serves as an advanced treatment unit for complete TSS removal and as a barrier to microorganisms (Hashemi 2015, Zuriaga-Agustí et al. 2016). However, MBRs are still facing a major operating problem: membrane fouling (Hashemi et al. 2016a, b; Zuriaga-Agustí et al. 2016). Hashemi et Khodabakhshi reported that the use of granular activated carbon within a MBR reduces membrane fouling while also removing a significant level of recalcitrant and the biorefractory compound found in composting leachates (Hashemi and Khodabakhshi 2016). Studies on composting leachate treatment using MBRs have reported the use of different combinations of bioreactors and membrane configurations: sequential bioreactors (SBR) (Laitinen 
Table 6 Operating conditions of MBRs applied to composting leachate treatment

\begin{tabular}{|c|c|c|c|c|c|c|}
\hline $\begin{array}{l}\text { Membrane bioreactor configuration } \\
\text { (Biological process/membrane } \\
\text { module) }\end{array}$ & $\begin{array}{l}\text { MLSS } \\
(\mathrm{g} / \mathrm{L})\end{array}$ & $\begin{array}{l}\text { MLVSS } \\
(\mathrm{g} / \mathrm{L})\end{array}$ & $\begin{array}{l}\text { HRT } \\
\text { (h) }\end{array}$ & $\begin{array}{l}\text { SRT } \\
\text { (days) }\end{array}$ & $\begin{array}{l}\text { OLR } \\
(\mathrm{kg} \mathrm{COD} / \\
\left.\mathrm{m}^{3} / \text { day }\right)\end{array}$ & Authors \\
\hline SBR/submerged & - & - & 72 & $35-60$ & - & Laitinen et al. (2006) \\
\hline SBR/submerged & $4-11$ & - & 16 & - & $0.13-8.03$ & Hashemi (2015) \\
\hline SBR/Submerged & $4-11$ & & $12-23$ & - & $0.01-10.7$ & $\begin{array}{l}\text { Hashemi and Khodabakhshi } \\
\text { (2016) }\end{array}$ \\
\hline Aerobic-anaerobic/external & $13.1-27.8$ & $10.1-18.7$ & - & - & - & Zuriaga-Agustí et al. (2016) \\
\hline Aerobic/submerged & - & - & 2.3 & - & 1.2 & Brown et al. (2013) \\
\hline
\end{tabular}

et al. 2006; Hashemi 2015; Hashemi and Khodabakhshi 2016) and aerobic tank (Brown et al. 2013; García-López et al. 2014) (both combined with submerged membranes), and aerobic-anaerobic bioreactors combined with external membranes (ZuriagaAgustí et al. 2016). Composting leachate treatment efficiencies for each of these MBR configurations are summarized in Table 4. Operating conditions for MBRs applied to composting leachate treatment are presented in Table 6 .

As expected with membrane filtration processes, MBRs TSS removals range from 99.8 to $99.9 \%$. The aerobic tank/submerged membrane configuration have the highest COD and ammoniacal nitrogen removal performances $(99.7 \%$ and $99.9 \%$, respectively) (Brown et al. 2013). While these removal efficiencies are promising for the use of MBRs for composting leachate treatment, Brown et al. (2013) operated their MBR under impracticable conditions: the hydraulic retention time (HRT) was unrealistically high at 2289 h (95 days). Furthermore, the MBR was only fed during 39 days, which means that the authors have never completed a single hydraulic residence time (95 days) during their experiment.

In addition to having few studies conducted on composting leachate treatment using MBRs, little information is available on the operating conditions. Operating parameters, such as mixed liquor suspended solids concentration (MLSS), HRT, and solid retention time (SRT) have direct effects on MBR performances, and need to be reported when assessing the performances of MBR. Thus, there is a significant lack of disclosing of information regarding the use of MBR for composting leachate treatment.

\subsubsection{Wetlands}

Due to the fertilizing properties of composting leachates, Bakhshoodeh et al. (2017) studied their treatment by subsurface horizontal flow constructed wetland. Five months after planting Vetiveria zizanioides, results showed significant removal efficiencies (74.5\% of BOD5, $53.7 \%$ of COD, and $69.9 \%$ of $\mathrm{N}-\mathrm{NH} 3$ ). While this management method is limited to warmer climates, it has the potential to be used as a leachate pretreatment (Bakhshoodeh et al. 2017).

\subsection{Physico-chemical treatment}

Several studies reported the use of different physicochemical treatment technologies. These studies are reported here in two categories: (1) Coagulationflocculation, and (2) Membrane filtration. The summary of their treatment efficiencies are reported in Table 7.

\subsubsection{Coagulation-flocculation}

Coagulation and flocculation processes are efficient for the removal of particulate fractions of wastewaters (particular matter, colloids, clays, etc.), high molecular weight organic fractions (humic acids, fulvic acids) and phosphorus.

Mahvi et al. (2015) tested different coagulants (ferrous sulfate, ferric chloride, poly ferric sulfate, alum and poly aluminum chloride), along with two anionic and cationic commercial co-coagulants: K350CF and LT25, for the removal of COD and TSS from composting leachates. The use of poly ferric sulfate with a $\mathrm{pH}$ of 11 with $2 \mathrm{~g} / \mathrm{L}$ of a coagulant, resulted in the highest removal rates with COD and 


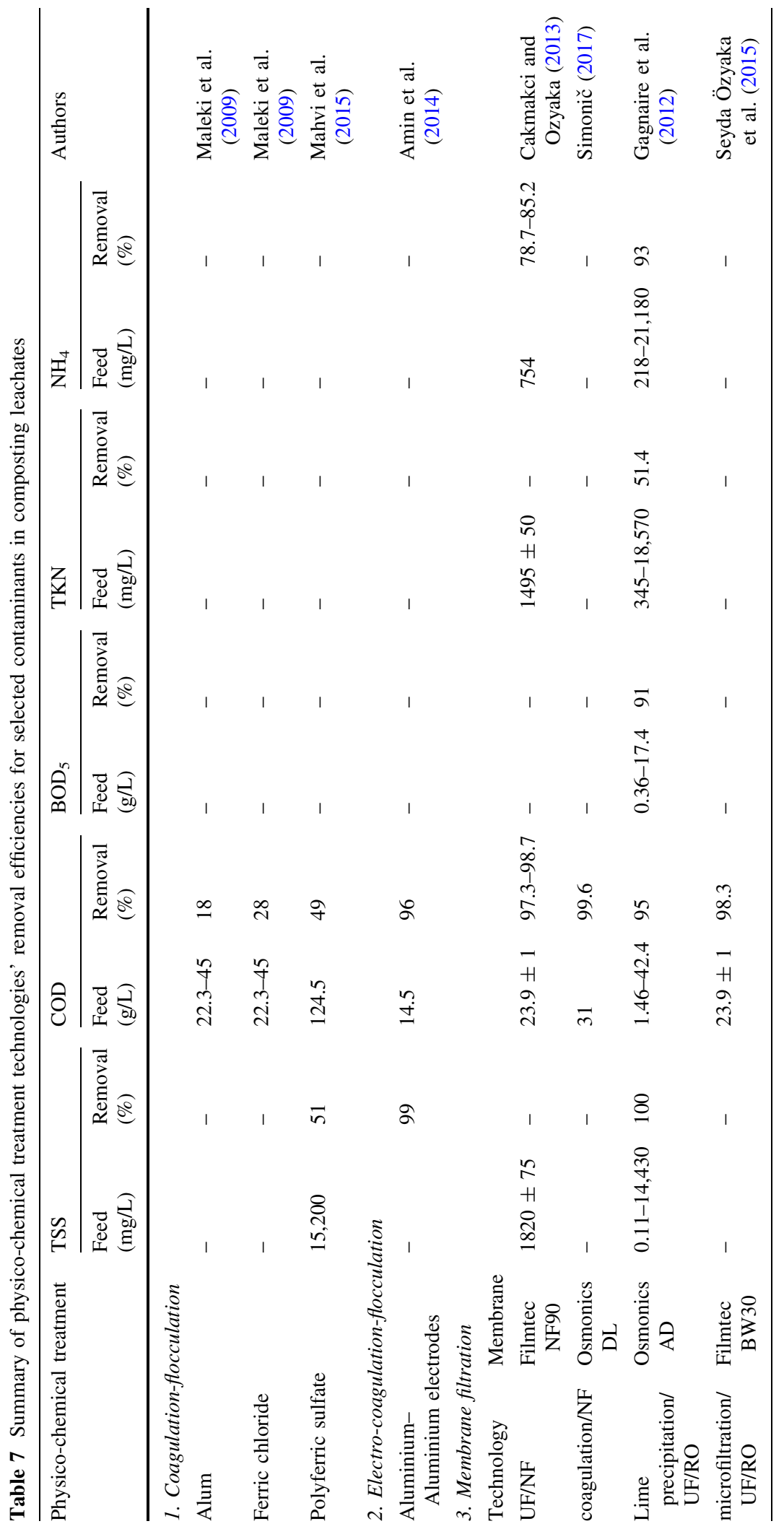


TSS removals of $49 \%$ and $51 \%$, respectively. On the other hand, Angadi et al. (2015) tested coagulationflocculation for heavy metal removal (Angadi et al. 2015). The combination of alum $(1 \mathrm{~g} / \mathrm{L})$ with polyelectrolyte $(0.3 \mathrm{~g} / \mathrm{L})$ at $\mathrm{pH} 7$ provided the highest performances with removals of $92.4 \%, 77.3 \%$ and $80.1 \%$ for cadmium, chromium, and nickel, respectively. Another study conducted by Maleki et al. (2009) also showed very efficient removals of heavy metals (Cd, Cr, Cu, Zn, Ni) (> 90\%) despite low COD removal $(18 \%)$ using alun $(1.4 \mathrm{~g} / \mathrm{L})$ at a $\mathrm{pH}$ of 6.5 (Maleki et al. 2009). The treatment efficacies of each of these combinations of coagulant and flocculent are summarized in Table 7.

The use of coagulation-flocculation as a standalone process for composting leachate treatment has been well discussed in terms of removal efficiencies for COD, TSS and heavy metals. However, studies are lacking information regarding some important contaminants such as ammoniacal nitrogen and phosphorus. Furthermore, the production of sludge and the associated management cost have not been discussed.

\subsubsection{Electro-coagulation/flotation}

Electro-coagulation-flotation (ECF) is a physicochemical treatment method that relies on the conduction of DC current in polluted wastewater and the dissolution of metallic electrodes (monopolar or bipolar connection) without the addition of chemical substances. Flotation is also provided, by means of aeration equipments and from the chemical reduction of water in gaseous hydrogen at the cathode, in order to enhance mixing and avoid concentration polarization (Amin et al. 2014). The advantages of ECF are: simplicity of design and operation, low retention time, low sludge production, lack of chemical addition, and fast sedimentation of flocs (Elyasi, Amani et al. 2015). However, the applications of EFC are limited to COD, phosphorus and TSS removal. Treatment efficacies of the ECF process are summarized in Table 7.

Amani et al. (2014) conducted a study on raw composting leachates in order to analyze and correlate the interactive effects of operational factors (such as influent COD, voltage, electrolysis time (ET), and electrode distance (ED)) on the efficiency of COD and TSS removal for various electrode configurations (Al$\mathrm{Al}, \mathrm{Al}-\mathrm{Fe}, \mathrm{Fe}-\mathrm{Al}, \mathrm{Fe}-\mathrm{Fe})$. Their results indicated that the best arrangement ( $\mathrm{Al}-\mathrm{Al})$ provided the higest removal efficiencies (96\% of COD and 99\% of TSS) in the following conditions: voltage $=21 \mathrm{~V}$, $\mathrm{ET}=75 \mathrm{~min}$, and $\mathrm{ED}=3 \mathrm{~cm}$ (Amin et al. 2014; Amani et al. 2015).

Following this study, the same group of researchers conducted two studies in which ECF was used as a post-treatment for anaerobic biological treatments in order to meet discharge criteria. In both studies, the ECF reactor was set up to follow the previously identified ideal conditions. In the first study, conducted on the effluent of an anaerobic baffled reactor (ABR), the EFC post-treatment increased COD and TSS removal by an average of 8 and $9 \%$, respectively (Elyasi et al. 2015). In the second study, conducted on the effluent of an expanded granular sludge bioreactor (EGSB), the ECF reactor increased COD and TSS removal up to 21 and 53\%, respectively (Dastyar et al. 2015). In both cases, the ECF increased the quality of the effluent up to discharge standards, regarding both TSS and COD concentrations. However, ECF cannot be used as a standalone process due to its lack of efficiency for the treatment of nitrogen contaminants.

\subsubsection{Filtration}

Membrane filtration has been used for a large range of industrial applications (Roy et al. 2017), including composting leachate treatment. The filtration capacities (flux and removal) of membrane technologies are significantly affected by the molecular weight cut off and manufacturing materials of the membrane layers (Simonič 2017). The main advantages of membrane filtration are the commercial availability of a large range of membranes with a large range of molecular weight cut-offs (MWCO), and the production of a treated water (permeate) with a constant quality notwithstanding contaminant concentration variations in the feed. Despite the continuous improvement of membranes, high operating costs when compared to conventional biological treatments as well as membrane fouling remain the major drawbacks of membrane filtration technologies. Furthermore, the management of the concentrate can also be a major issue regarding the application.

In order to produce safely disposable wastewater from composting leachates, the use of nanofiltration (NF) and reverse osmosis (RO) have been studied and the separation efficiencies are summarized in Table 7. Using NF technology, Cakmakci and Ozyaka (2013) 
tested four membranes: the NP030 and NP010 (Microdyn Nadir), and the NF270 and NF90 (DowFilmtec). Simonic (2017) tested two other NF membranes: the DK and DL (Osmonics Desal). In order to prevent clogging of the membrane units with TSS, pretreatment was applied in both studies. Cakmakci \& Ozyaka (2013) used a UC030 ultrafiltration membrane (MWCO of $30 \mathrm{kDa}$ ) and reported an initial COD removal of $17 \%$ and no significant removal of $\mathrm{NH}_{4}{ }^{+}$. Simonic (2017) used polyaluminium chloride $(10 \mathrm{~mL} /$ $\mathrm{L})$ as a coagulant agent and reported an initial COD and colloid removal of $75 \%$. Then, the use of NF90 and DL membranes resulted in the highest COD removal efficiencies (98.7 and 99.6\%, respectively). Cakmakci and Ozyaka (2013) also reported $\mathrm{NH}_{4}{ }^{+}$ removals between 79 and $85 \%$, which correlates to the percentage of dissolved combined amino acids (Cakmakci and Ozyaka 2013; Simonič 2017).

Using RO technology, Gagnaire et al. (2012) tested the AD (Osmonics Desal), and Seyda Özyaka et al. (2015) tested both the BW30 and SW30 (DowFilmtec). As for NF, pretreatment was necessary in order to prevent the clogging of the membranes. Gagnaire et al. (2012) used chemical precipitation using lime, followed by an ultrafiltration (MWCO of $150 \mathrm{kDa}$ ). They reported an optimum lime dose of $384 \mathrm{mg} \mathrm{N}-\mathrm{NH}_{4} / \mathrm{g} \mathrm{Ca}(\mathrm{OH})_{2}$, which resulted in $\mathrm{N}_{-} \mathrm{NH}_{4}$ and COD removals of 45-77 and 48\%, respectively. The nanofiltration that followed increased COD removal by $8 \%$, leading to total removals of 56 and $>99.9 \%$ for COD and TSS, respectively. Seyda Özyaka et al. (2015) used a sequence of micro and ultrafiltration membranes, namely the MP005 and ZW-UF, respectively. They reported $12 \%$ COD removal. Then, the use of BW30 and $A D$ RO membranes resulted in COD removals of 98.3 and 95\%, respectively. Again with the BW30 membrane, Gagnaire et al. (2012) also reported TSS, BOD 5 and $\mathrm{N}-\mathrm{NH}_{4}{ }^{+}$removals of 100,91 and $93 \%$, respectively (Gagnaire et al. 2012; Seyda Özyaka et al. 2015).

In terms of fouling, the direct use of RO membranes is not viable. An instantaneous loss of $80 \%$ in permeate flow is observed as soon as raw composting leachate filtration begins (Gagnaire et al. 2012). According to Simonic (2017), the main foulant material could be hydrophobic natural organic matter (NOM). They observed that NOM fouling layers lead to cake enhanced concentration polarization (Hoek and Elimelech 2003; Simonič 2017). Combined with an appropriate pre-treatment, $\mathrm{NF}$ and $\mathrm{RO}$ membranes represent a promising solution for $\mathrm{COD}, \mathrm{NH}_{4}$ and TSS removal in composting leachate.

\subsection{Advanced technologies}

Advanced oxidation processes (AOPs) differ from conventional oxidation process in their capacity of producing hydroxyl radicals $(\mathrm{OH} \cdot)$, a highly reactive oxidative agent. Due to their high reactivity and nonselectivity, hydroxyl radicals are able to oxidize organic matter efficiently (Matilainen and Sillanpää 2010). Therefore, over the past few decades, the use of AOPs for the treatment of complex and refractory organic contaminants in wastewater gained in popularity (Wang et al. 2003). Due to the high organic content of composting leachates, the uses of AOPs as a primary treatment is not advantageous since the oxidant species consumption would be too high. Despite this consideration, an attempt at composting leachate treatment by Fenton reaction was performed by Trujillo et al. (2006). Under the optimal conditions for Fenton's reaction $\left(\left[\mathrm{Fe}_{2}{ }^{+}\right] /[\mathrm{COD}]=0.1\right.$ with $\left.\left[\mathrm{H}_{2} \mathrm{O}_{2}\right] /[\mathrm{COD}]=1\right)$, they obtained COD and BOD5 removals of 75-77 and 90-98\%, respectively (Trujillo et al. 2006).Other AOPs, such as $\mathrm{O}_{3}, \mathrm{O}_{3}$ /persulfate, $\mathrm{O}_{3} / \mathrm{H}_{2} \mathrm{O}_{2}$, and photocatalytic oxidation $\left(\mathrm{UV} / \mathrm{TiO}_{2}\right)$, have been investigated in terms of their efficiency as a post-treatment step of composting leachate treated by biological processes.

\subsubsection{AOPs for the post-treatment of biologically- treated composting leachates}

Due to the refractory nature of composting leachates organic contamination, biological processes are often insufficient in obtaining an effluent that meets disposal criteria. In order to develop a sufficient treatment, AOPs have been studied for their ability to improve the removal of these hardly biodegradable organic molecules. The efficiencies of the studied AOPs in the post-treatment of biologically treated composting leachates are summarized in Table 8 .

$\mathrm{O}_{3}$ is a widely used oxidant in wastewater treatment. Mokhtarani et al. (2014) and Soubh and Mokhtarani (2016) studied the single ozonation process in the post-treatment of low COD $(<1 \mathrm{~g} / \mathrm{L})$ treated composting leachate. COD removals were similar in both studies (51 and 40\%) (Mokhtarani et al. 


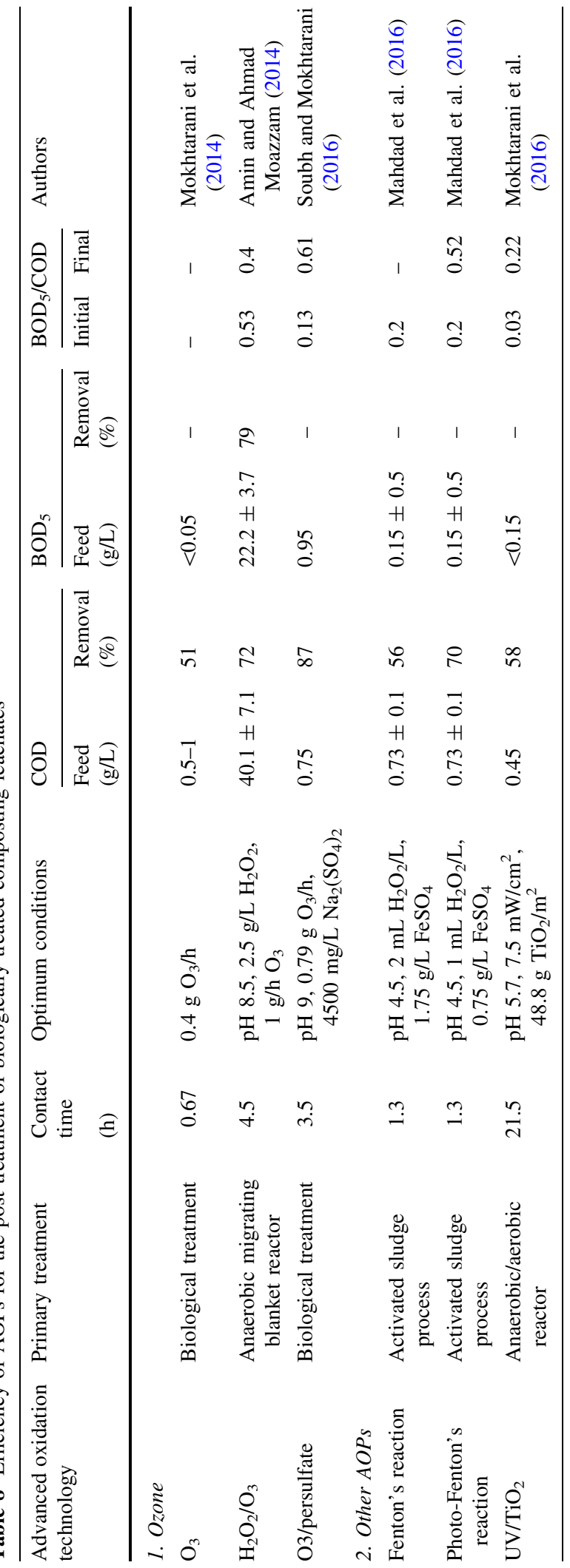


2014, Soubh and Mokhtarani 2016). However, Soubh et al. reported a higher efficiency with an ozone consumption rate of $1.16 \mathrm{mg} \mathrm{O}_{3} / \mathrm{mg}$ COD compared to the $2.8-4.1 \mathrm{mg} \mathrm{O}_{3} / \mathrm{mg} \mathrm{COD}$ rate obtained by Mokhtarani et al. (2014) despite the fact that they were using similar reactors. In order to improve the COD removal, Soubh and Mokhtarani (2016) also tested the combination of $\mathrm{O}_{3}$ /persulfate(Soubh and Mokhtarani 2016). The addition of $4500 \mathrm{mg} / \mathrm{L}$ of persulfate increased the COD removal rate from 40 to $87 \%$, and increased the $\mathrm{BOD}_{5} / \mathrm{COD}$ from 0.13 to 0.61 . The combination of $\mathrm{O}_{3} / \mathrm{H}_{2} \mathrm{O}_{2}$ has also been tested as a posttreatment for high strength composting leachates $(\mathrm{COD}=40.1 \pm 7.1 \mathrm{mg} / \mathrm{L})$. Despite high initial concentrations, the $\mathrm{O}_{3} / \mathrm{H}_{2} \mathrm{O}_{2}$ process reduced the COD and $\mathrm{BOD}_{5}$ concentrations by 72 and $79 \%$, respectively(Amin and Ahmad Moazzam 2014). However, compared to the $\mathrm{O}_{3}$ /persulfate process, the $\mathrm{O}_{3} / \mathrm{H}_{2} \mathrm{O}_{2}$ process reduced the $\mathrm{BOD}_{5} / \mathrm{COD}$ from 0.53 to 0.4 , indicating that biodegradable organic matter is more likely to be oxidized when using $\mathrm{H}_{2} \mathrm{O}_{2}$. This observation is in accordance with the findings of Trujillo et al. (2006).

A conventional Fenton process and a photo-Fenton process (combination of Fenton's reagent with UV light to further increase hydroxyl radical production) were compared as post-treatment. With regard to Fenton oxidation ( $\mathrm{pH}$ of $4.5,1.75 \mathrm{~g} / \mathrm{L} \mathrm{FeSO}_{4}$, and $2 \mathrm{ml} / \mathrm{L} \mathrm{H}_{2} \mathrm{O}_{2}$ ), 55.9\% COD and $65.7 \%$ colour were removed. With regard to photo-Fenton ( $\mathrm{pH}$ of 4.5 , $0.75 \mathrm{~g} / \mathrm{L} \mathrm{FeSO}_{4}$, and $1 \mathrm{ml} / \mathrm{H}_{2} \mathrm{O}_{2}$ ), $73.8 \% \mathrm{COD}$ and $83.6 \%$ colour were removed. Results also indicated that the biodegradability of the effluent increased with the photo-Fenton process $\left(\mathrm{BOD}_{5} / \mathrm{COD}\right.$ of $0.52 \mathrm{com}-$ pared to 0.2) (Mahdad et al. 2016).

The emerging $\mathrm{UV} / \mathrm{TiO}_{2}$ photocatalytic oxidation process was also investigated as a post-treatment. This process generates in situ hydroxyl radicals under ambient conditions. When the $\mathrm{TiO}_{2}$ catalyst is exposed to UV radiation, an electron $\left(\mathrm{e}^{-}\right)$-hole $\left(\mathrm{h}^{+}\right)$pair is produced. In most cases, on the surface of the catalyst, $\mathrm{h}^{+}$reacts easily with surface-bound $\mathrm{H}_{2} \mathrm{O}$ to produce $\mathrm{OH} \bullet$ free radicals and $\mathrm{H}^{+}$(Mokhtarani et al. 2016). In addition to being the first to report the use $\mathrm{UV} / \mathrm{TiO}_{2}$ in composting leachate post-treatment, Mokhtarani et al. (2015) also chose to immobilize the $\mathrm{TiO}_{2}$ nanoparticles on a concrete surface. After $21.5 \mathrm{~h}$ of radiation with $7.5 \mathrm{~mW} / \mathrm{cm}^{2}$ light intensity, the maximum COD and colour removal achieved were 58 and $36 \%$, respectively. The biodegradability of the effluent also increased $\left(\mathrm{BOD}_{5} / \mathrm{COD}\right.$ of 0.22 compared to 0.03 ) (Mokhtarani et al. 2016).

AOPs are efficient technologies to use in the removal of refractory organic contamination $\left(\mathrm{BOD}_{5} /\right.$ $\mathrm{COD}<0.2)$ found in composting leachates. Since they are more largely effective for COD and colour removal, AOPs should be considered as a biologicallytreated effluent post-treatment. However, the addition of a physico-chemical technology should still be considered in order to remove TSS.

\subsection{Composting leachate reuse and transformation}

Composting leachate treatment comes with costs of operation, labor, and time. To transform these costs into profit, studies have proposed solutions that create added-value products or reuse composting leachate to replace commercial products.

Justin et al. (2010) compared the impact of landfill versus composting leachates on the growth of Salix species and Populus. The beneficial attributes of these tree species include: an appropriate phytoremediation capacity, a tolerance for extreme growing conditions, and a high-yield of biomass production. This biomass can, for instance, be transformed for fuel, chipboard, paper, and charcoal production. Despite the high nutrient content (up to $1105 \mathrm{mg} / \mathrm{L} \mathrm{N}, 372 \mathrm{mg} / \mathrm{L} \mathrm{P}$ and $2888 \mathrm{mg} / \mathrm{L} \mathrm{K}$ ) of composting leachate, there seemed to be less potential for its use due to its high concentrations variability (Justin et al. 2010). Over the course of the same year, Zhou et al. (2010) conducted a similar study using composting leachates to irrigate Impatiens, a common garden flower (Zhou et al. 2010). However, instead of using raw composting leachates, they added a microbial culture to the leachate and stored the mixture for nine weeks. This preconditioning reduced the $\mathrm{COD}$ and $\mathrm{BOD}_{5}$ concentration by 9.6 and $6.7 \%$ respectively. Then, they diluted the conditioned leachate $(1: 10)$ before the irrigation in order to balance the nutrients concentrations. In contrast to the results of Justin et al. (2010), the use of pretreated composting leachates promoted the growth of Impatiens. Other composting leachate preconditioning techniques to reduce organic contamination have also been studied, such as the use of bioreactors with various HRT. Romero et al. (2013) used an anaerobic continuous stirred tank reactor (ACSTR) to reduce the COD of the raw leachate (87\% 
removal) (Romero et al. 2013). While no significant effect was observed on the germination index, the biological treatment reduced odour.

In order to transform composting leachates contamination in a value-added product, Liu et al. (2015) evaluated the possibility of fermentative hydrogen $\left(\mathrm{H}_{2}\right)$ production using leachates as an alternative source of nutrients (Liu et al. 2015). To compensate for the lack of phosphorus required for fermentative $\mathrm{H}_{2}$ production, orthophosphate and pyrophosphate were separately added into leachate. With COD/P ratio of 27.6/1 at $\mathrm{pH}$ of 5, the $\mathrm{H}_{2}$ yield obtained was $1.95 \mathrm{~mol} \mathrm{H}_{2} / \mathrm{mol}$ glucose. These results are promising for future usage of fresh leachate and phosphate contained waste for biohydrogen production.

The transformation and reuse of composting leachates would bring environmental benefits through the planting of green areas, which would in turn help contain and limit erosion while also increasing carbon sequestration. Furthermore, compost leachates can replace chemical fertilizer in organic cultivation farms (Kim et al. 2015). Nevertheless, these alternative approaches have certain obstacles to overcome before becoming technically feasible. Major issues include the presence of: toxic organic compounds with low molecular weights (Romero et al. 2013), high concentrations of $\mathrm{COD}$ and $\mathrm{BOD}_{5}$, phytotoxic substances like and ammonia, and high concentrations of TDS. Furthermore, the presence of heavy metals can cause partial damage to plant leaves, reduce their chlorophyll production, and can be bioacculumated in the plants.

\subsection{Operation costs of leachate treatment technologies}

Operating cost is a major factor when selecting the appropriate leachate treatment technology. Among all the technology studied for the treatment of composting leachates, biological treatment appears to be the most economical option with operating costs ranging from 0.20 to $3.20 \mathrm{USD} / \mathrm{m}^{3}$ (Robinson 2005; Kurniawan et al. 2006; Cassano et al. 2011). Robinson (2005) conducted a comprehensive analysis on MBR's operating costs and found that MBR can treat leachates with costs ranging from 0.20 to $0.75 \mathrm{USD} / \mathrm{m}^{3}$ (Robinson 2005). Membrane filtration is also a technology of choice for leachate treatment. As a standalone treatment, $\mathrm{RO}$ has operating costs ranging from 3.80 to $10 \mathrm{USD} / \mathrm{m}^{3}$ (Thörneby et al. 2003; Kurniawan et al. 2006). Combined with a pretreatment such as UF membranes, the operating cost is reduced from 0.80 to $1.05 \mathrm{USD} / \mathrm{m}^{3}$ (Ozturk et al. 2003). However, this cost does not take into account concentrate management, which can be prohibitive for leachates with a high dissolved solids content.

The operating costs of physico-chemical treatments for ammoniacal nitrogen, such as air stripping and struvite precipitation, is 0.52 and $2-4.45 \mathrm{USD} / \mathrm{m}^{3}$, respectively (Ozturk et al. 2003; Kurniawan et al. 2006). Despite having similar operating costs as biological treatment, these technologies are only effective on one contaminant, and they also have to be incorporated in a sequence of technologies. Thus, the entire treatment can quickly become costly. A similar analysis can be done for coagulation coupled with activated carbon. The operating cost of this technology is approximately $2.30 \mathrm{USD} / \mathrm{m}^{3}$, though it only removes soluble organic contaminants and suspended solids (Kurniawan et al. 2006). RO coupled with NF has similar operating costs, and therefore seems to be a better economical and technical option in terms of physico-chemical treatment technology.

Similarly to physico-chemical technologies, advanced oxidation technologies cannot be used standalone due to the high concentration of organic pollutants in the composting leachates. The operating cost of $\mathrm{O}_{3}$ used as a post-treatment ranges from 0.90 to $4 \mathrm{USD} / \mathrm{m}^{3}$ (Tizaoui et al. 2007; Cassano et al. 2011) and its combination with $\mathrm{H}_{2} \mathrm{O}_{2}(2 \mathrm{~g} / \mathrm{L})$ costs approximately $3.05 \mathrm{USD} / \mathrm{m}^{3}$ (Tizaoui et al. 2007). The Fenton's process as a standalone technology is even more costly, with operating costs ranging from 1.30 to $17.10 \mathrm{USD} / \mathrm{m}^{3}$ (Singh et al. 2013). A potentially economical option to consider is the use of the Fenton's process as a pre-treatment to improve the biodegradability of the organic contaminants before of a biological treatment. Xie et al. (2010) estimated the operating cost of the combination of the Fenton's process with a biofilter at $2.10 \mathrm{USD} / \mathrm{m} 3$, which is in the range of costs of biotreatment technologies (Xie et al. 2010).

Finally, thermal technology operating costs have also been assessed. With operating costs ranging from 30 to $70 \mathrm{USD} / \mathrm{m}^{3}$ (evaporation and thermal oxidation), these technologies should only be considered as a last resort, despite their very high removal efficacy for 
almost all contaminants ( $>99 \%$ removal) (Ozturk et al. 2003).

\section{Summary}

The growing interest in the composting of organic waste will inevitably lead to an increase in composting leachate production. Composting leachate contamination is characterized by high concentrations of moderately biodegradable organic matter and nutrients, and by the presence of heavy metals and plasticizers, all of which exceed NRWQC criteria for freshwater aquatic life. Furthermore, concentrations of contaminants are highly variable due to two main factors: (1) the type of composted organic wastes (feedstock) and (2) the type of composting technology. The heterogeneous composition and seasonal variability of the feedstock both influence the composting leachate composition. The composting technology, on the other hand, influences the amount of water involved in the process and the oxic conditions inside the organic wastes being composted. The main contaminants of composting leachates are summarized and described in Table 9.

Despite the fact that the types of contaminants found in composting leachates are quite common, selecting and designing a water treatment technology capable of producing a safely disposable treated effluent poses a challenge due to the wide range of contaminant types and concentrations. To date, the treatment of composting leachate with biological (biofilters, anaerobic bioreactors and MBR), physico-chemical (coagulation-flocculation, electro-coagulation/flotation, nanofiltration and reverse osmosis), and advanced oxidation technologies (Fenton's reaction, $\mathrm{O}_{3}, \mathrm{O}_{3} / \mathrm{H}_{2} \mathrm{O}_{2}, \mathrm{O}_{3}$ /persulfate and $\mathrm{UV} /$ $\mathrm{TiO}_{2}$ ) have been reported in the literature.

Biological processes are the most financially sound solutions. MBRs operating costs are the lowest, ranging from 0.21 to $0.75 \mathrm{USD} / \mathrm{m}^{3}$. The most economical physico-chemical treatment option seems to be the combination of NF and RO (0.80-1.05 USD/ $\mathrm{m} 3$ ). However, the concentrate management cost can be prohibitive for leachates with high TDS concentrations. Finally, oxidation processes as standalone technologies are the most costly to operate (1.30-17.10 $\left.\$ / \mathrm{m}^{3}\right)$. However, combing them with biological processes as a pre- or post-treatment has the potential of being economical. In the present context, none of these technologies can produce an effluent meeting all NRWQC criteria, which is a major concern considering the increasing number of composting facilities. Thus far, MBRs and membrane filtration technologies are the most promising possibilities. Unlike the other proposed technologies, these two are efficient for the simultaneous removal of COD, TSS and $\mathrm{NH}_{4}$.

Table 9 Composting leachates contaminants properties

\begin{tabular}{|c|c|}
\hline \multicolumn{2}{|l|}{ Organic matter } \\
\hline Moderately biodegradable & $\mathrm{BOD}_{5} / \mathrm{COD} \pm 0.33$ \\
\hline High molecular weight & $1000-3000 \mathrm{kDa}$ \\
\hline Highly aromatic & Fulvic- and humic-like substances \\
\hline \multicolumn{2}{|l|}{ Presence of volatile fatty acids (VFAs) } \\
\hline Presence of toxic organic contaminants & DEHP, BPA \\
\hline \multicolumn{2}{|l|}{ Nitrogen } \\
\hline Proteinaceous and amines compounds & $75-85 \%$ \\
\hline Ammonium salts & $15-25 \%$ \\
\hline Highly biodegradable & $\mathrm{N}-\mathrm{NH}_{4} / \mathrm{NTK}>0.5$ \\
\hline \multicolumn{2}{|c|}{ Integrated to fulvic- and humic-like substances } \\
\hline \multicolumn{2}{|l|}{ Heavy metals } \\
\hline Common heavy metals & $\mathrm{Cd}, \mathrm{Cu}, \mathrm{Ni}, \mathrm{Pb}$ and $\mathrm{Zn}$ \\
\hline Complexation properties & $\begin{array}{l}\text { Strong complexation capability } \\
\text { with fulvic- and humic like } \\
\text { substance }\end{array}$ \\
\hline Solubility & High, due to complexation \\
\hline
\end{tabular}




\section{Conclusion}

To face the growing production of composting leachates and provide an integrated solution for the treatment of this particular wastewater, further researches are required. In the light of the information presented in this review paper, future research perspectives in the field of composting leachate treatment are the following.

1. The presence of toxic organic pollutants in composting leachates have been reported by Fromme et al. (2002) and Marttinen et al. (2004). However, no subsequent studies conducted on the treatment of composting leachates have assessed the presence of TOPs or the capacity of the different technologies to treat these contaminants. Thus, in the future, the fate of TOPs during the leachate treatment should be considered.

2. As mentioned in Sect. 3.1, there is a significant lack of information disclosure regarding the use of MBR for composting leachate treatment. In order to fill this information gap, composting leachate contaminant removal kinetics in aerobic and anaerobic MBR should be studied. This information is required in order to design reactors with suitable operating conditions and optimal removal efficiencies. Furthermore, economical and technical comparison with conventional technologies (such as aerated lagoons or activated sludge) should be performed when assessing the efficiency of more complex biological technologies.

3. The operation of a MBR based on the principle of UCT-type processes for the treatment of composting leachate should be studied. UCT-type processes consist of a series of anaerobic, anoxic, and aerobic biological reactors. The combination of these oxic conditions provides significant advantages compared to other biological treatment technologies, namely, the enhanced COD and phosphorus removal efficiencies, and nitrification and denitrification reaction completions over the course a single process (Kuba et al. 1997). Considering the reported treatment efficiencies of single tank MBR for the treatment of composting leachates, the addition of a UCT-type process could produce an effluent that meets the NRWQC criteria without further treatment.
4. Along with the development of a UCT-MBR, other process combinations should be considered. The combination of biological treatment with advanced oxidation process pre- and post-treatment is a financially and technically attractive solution. Biological treatment processes have the ability to reduce the nitrogen and biodegradable organic contamination at low cost, while the AOPs are able to oxidize refractory organic compounds and TOPs. A promising combination that should be analyzed for further development is the MBR-AOP. In addition to the submerged membrane of the MBR completely removing the TSS, the bioreactor could be operated with low HRT since any untreated COD would be removed by the AOP post-treatment.

5. Further research should be conducted in the use of composting leachates as a culture media in the production of value-added molecules with high market values. This solution would increase the profitability of composting facilities, making them an even more feasible waste management solution.

Acknowledgements Support for this study was provided by the RDC and RDA-II programs from NSERC, under a cooperative agreement with the Institut national de la recherche scientifique (INRS), Englobe Corp., and Centre National en Électrochimie et en Technologies Environnementales (CNETE); and by a MITACS doctoral scholarship from MITACS and Englobe Corp. The author would also like to thank Dr. Mohamed Rahni for revising this manuscript and Ms. Nathalie Couët for copy editing.

\section{References}

Agency, U. S. E. P. (1986). Quality criteria for water-1986

Agency, U. S. E. P. (1994). Water quality standards handbook: second edition, 202

Agency, U. S. E. P. (2014) "Summary Table for the Nutrient Criteria Documents.” Retrieved 2017-09-01, 2017, from https:// www.epa.gov/sites/production/files/2014-08/documents/ criteria-nutrient-ecoregions-sumtable.pdf

Agency, U. S. E. P. (2017, 2017-07-20). National Recommended Water Quality Criteria-Aquatic Life Criteria Table. Retrieved 2017-09-01, 2017, from https://www.epa.gov/ $\mathrm{wqc} /$ national-recommended-water-quality-criteria-aquaticlife-criteria-table

Amani T, Veysi K, Elyasi S, Dastyar W (2014) A precise experimental study of various affecting operational parameters in electrocoagulation-flotation process of high- 
load compost leachate in a batch reactor. Water Sci Technol 70(8):1314-1321

Amani T, Veysi K, Dastyar W, Elyasi S (2015) Studying interactive effects of operational parameters on continuous bipolar electrocoagulation-flotation process for treatment of high-load compost leachate. Int J Environ Sci Technol 12(8):2467-2474

Amin M, Ahmad Moazzam M (2014) Advanced oxidation treatment of composting leachate of municipal solid waste by ozone-hydrogen peroxide. Int $\mathrm{J}$ Environ Health Eng 3(1):21

Amin MM, Hashemi H, Ebrahimi BBA, Pourzamani HR, Ebrahimi A (2014) Environmental pollutants removal from composting leachate using anaerobic biological treatment process. Int J Health Syst Disaster Manag 2(3):6

Amlinger F, Götz B, Dreher P, Geszti J, Weissteiner C (2003) Nitrogen in biowaste and yard waste compost: dynamics of mobilisation and availability-a review. Eur J Soil Biol 39(3): 107-116

Angadi SS, Shetty R, Manjunath NT (2015) Coagulation study to remove heavy metals from leachate. Int J Innov Res Sci Eng Technol 4(6):4095-4099

Assiry AM, Gaily MH, Alsamee M, Sarifudin A (2010) Electrical conductivity of seawater during ohmic heating. Desalination 260(1):9-17

Bakhshoodeh R, Alavi N, Majlesi M, Paydary P (2017) Compost leachate treatment by a pilot-scale subsurface horizontal flow constructed wetland. Ecol Eng 105:7-14

Bilgili MS, Demir A, Özkaya B (2007) Influence of leachate recirculation on aerobic and anaerobic decomposition of solid wastes. J Hazard Mater 143(1):177-183

Bolea E, Laborda F, Castillo JR (2010) Metal associations to microparticles, nanocolloids and macromolecules in compost leachates: size characterization by asymmetrical flow field-flow fractionation coupled to ICP-MS. Anal Chim Acta 661(2):206-214

Brown K, Ghoshdastidar AJ, Hanmore J, Frazee J, Tong AZ (2013) Membrane bioreactor technology: a novel approach to the treatment of compost leachate. Waste Manag 33(11):2188-2194

Cakmakci M, Ozyaka VS (2013) Aerobic composting leachate treatment by the combination of membrane processes. Waste Manage Res 31(2):187-193

Cassano D, Zapata A, Brunetti G, Del Moro G, Di Iaconi C, Oller I, Malato S, Mascolo G (2011) Comparison of several combined/integrated biological-AOPs setups for the treatment of municipal landfill leachate: minimization of operating costs and effluent toxicity. Chem Eng J 172(1):250-257

Chatterjee N, Flury M, Hinman C, Cogger CG (2013). Chemical and physical characteristics of compost leachates-a review (No. WA-RD 819.1)

Cho JK, Park SC, Chang HN (1995) Biochemical methane potential and solid state anaerobic digestion of Korean food wastes. Biores Technol 52(3):245-253

Cole MA (1994) Assessing the impact of composting yard trimmings. BioCycle 35(4):92-96

Dastyar W, Amani T, Elyasi S (2015) Investigation of affecting parameters on treating high-strength compost leachate in a hybrid EGSB and fixed-bed reactor followed by electrocoagulation-flotation process. Process Saf Environ Prot 95:1-11

de Guardia A, Brunet S, Rogeau D, Matejka G (2002) Fractionation and characterisation of dissolved organic matter from composting green wastes. Biores Technol 83(3):181-187

Elyasi S, Amani T, Dastyar W (2015a) A comprehensive evaluation of parameters affecting treating high-strength compost leachate in anaerobic baffled reactor followed by electrocoagulation-flotation process. Water Air Soil Pollut 226(4): 116

Eslami H, Hashemi H, Fallahzadeh RA, Khosravi R, Fard RF, Ebrahimi AA (2018) Effect of organic loading rates on biogas production and anaerobic biodegradation of composting leachate in the anaerobic series bioreactors. Ecol Eng 110:165-171

Fondriest Environmental I (2014-04-03) “Conductivity, Salinity and Total Dissolved Solids." Fundamentals of Environmental Measurements.Retrieved 2017-07-25, 2017, from http://www.fondriest.com/environmental-measurements/ parameters/water-quality/conductivity-salinity-tds/

Forgie DJL, Sasser LW, Neger MK (2004) Compost facility requirements guideline, how to comply with part 5 of the organic matter recycling regulation. Ministry of water, land and air protection

Fromme H, Küchler T, Otto T, Pilz K, Müller J, Wenzel A (2002) Occurrence of phthalates and bisphenol A and F in the environment. Water Res 36(6):1429-1438

Gagnaire J, Wang XY, Chapon L, Moulin P, Marrot B (2011) Kinetic study of compost liquor nitrification. Water Sci Technol 63(5):868-876

Gagnaire J, Chapon L, Moulin P, Marrot B (2012) Physicochemical treatment applied to compost liquor: feasibility study. J Ind Eng Chem 18(4):1522-1528

García-López J, Rad C, Navarro M (2014) Strategies of management for the whole treatment of leachates generated in a landfill and in a composting plant. J Environ Sci Health, Part A 49(13):1520-1530

Gutiérrez-Miceli FA, García-Gómez RC, Oliva-Llaven MA, Montes-Molina JA, Dendooven L (2017) Vermicomposting leachate as liquid fertilizer for the cultivation of sugarcane (Saccharum sp.). J Plant Nutr 40(1):40-49

Hashemi H, Safari MA, Ebrahimi AS, Khodabakhshi AB (2015) Increasing of leachate quality using an integrated aerobic membrane bioreactor. J Adv Environ Health Res 3(1)

Hashemi H, Khodabakhshi A (2016) Complete treatment of compost leachate using integrated biological and membrane filtration processes $81-87$

Hashemi H, Ebrahimi A, Khodabakhshi A (2015) Investigation of anaerobic biodegradability of real compost leachate emphasis on biogas harvesting. Int J Environ Sci Technol 12(9):2841-2846

Hashemi H, Ebrahimi A, Mokhtari M, Jasemizad T (2016a) Removal of PAHs and heavy metals in composting leachate using the anaerobic migrating blanket reactor (AMBR) process. Desalin Water Treat 57(52):24960-24969

Hashemi H, Hajizadeh Y, Amin MM, Bina B, Ebrahimi A, Khodabakhshi A, Ebrahimi A, Pourzamani HR (2016b) Macropollutants removal from compost leachate using 
membrane separation process. Desalin Water Treat 57(16):7149-7154

Hashemi H, Zad TJ, Derakhshan Z, Ebrahimi AA (2017) Determination of sequencing batch reactor (SBR) performance in treatment of composting plant leachate. Health Scope 6(3):e13356. https://doi.org/10.5812/jhealthscope. 13356

Haug RT (1993) The practical handbook of composting engineering. CRC Press, Boca Raton

He X, Xi B, Wei Z, Guo X, Li M, An D, Liu H (2011) Spectroscopic characterization of water extractable organic matter during composting of municipal solid waste. Chemosphere 82(4):541-548

He X-S, Xi B-D, Zhang Z-Y, Gao R-T, Tan W-B, Cui D-Y, Yuan Y (2015) Composition, removal, redox, and metal complexation properties of dissolved organic nitrogen in composting leachates. J Hazard Mater 283:227-233

Henze M, Harremoes P, la Cour Jansen J, Arvin E (2002) Wastewater treatment: biological and chemical processes. Springer, Berlin Heidelberg

Hoek EMV, Elimelech M (2003) Cake-enhanced concentration polarization: a new fouling mechanism for salt-rejecting membranes. Environ Sci Technol 37(24):5581-5588

Judd S (2010) The MBR book: principles and applications of membrane bioreactors for water and wastewater treatment. Elsevier, Amsterdam

Justin MZ, Pajk N, Zupanc V, Zupančič M (2010) Phytoremediation of landfill leachate and compost wastewater by irrigation of Populus and Salix: biomass and growth response. Waste Manag 30(6):1032-1042

Kim J-D, Park J-S, In B-H, Kim D, Namkoong W (2008) Evaluation of pilot-scale in-vessel composting for food waste treatment. J Hazard Mater 154(1):272-277

Kim MJ, Shim CK, Kim YK, Hong SJ, Park JH, Han EJ, Kim JH, Kim SC (2015) Effect of aerated compost tea on the growth promotion of lettuce, soybean, and sweet corn in organic cultivation. Plant Pathol J 31(3):259-268

Krogmann U, Woyczechowski H (2000) Selected characteristics of leachate, condensate and runoff released during composting of biogenic waste. Waste Manag Res 18(3):235-248

Kuba T, Van Loosdrecht MCM, Brandse FA, Heijnen JJ (1997) Occurrence of denitrifying phosphorus removing bacteria in modified UCT-type wastewater treatment plants. Water Res 31(4):777-786

Kurniawan TA, Lo W-H, Chan GY (2006) Physico-chemical treatments for removal of recalcitrant contaminants from landfill leachate. J Hazard Mater 129(1):80-100

Kuster M, de Alda MJL, Hernando MD, Petrovic M, MartínAlonso J, Barceló D (2008) Analysis and occurrence of pharmaceuticals, estrogens, progestogens and polar pesticides in sewage treatment plant effluents, river water and drinking water in the Llobregat river basin (Barcelona, Spain). J Hydrol 358(1):112-123

Lafrance C, Lessard P, Buelna G (1996) Évaluation de la filtration sur tourbe et compost pour le traitement de l'effluent d'une usine de compostage de résidus verts. Can J Civ Eng 23(5):1041-1050

Laitinen N, Luonsi A, Vilen J (2006) Landfill leachate treatment with sequencing batch reactor and membrane bioreactor. Desalination 191(1):86-91
Liu CH, Lo KV (2001) Ammonia removal from composting leachate using zeolite. I. Characterization of the zeolite. J Environ Sci Health Part A Toxic/Hazard Subst Environ Eng 36(9):1671-1688

Liu J, Zhong J, Wang Y, Liu Q, Qian G, Zhong L, Guo R, Zhang $\mathrm{P}, \mathrm{Xu}$ ZP (2010) Effective bio-treatment of fresh leachate from pretreated municipal solid waste in an expanded granular sludge bed bioreactor. Biores Technol 101(5):1447-1452

Liu Q, Chen W, Zhang X, Yu L, Zhou J, Xu Y, Qian G (2015) Phosphate enhancing fermentative hydrogen production from substrate with municipal solid waste composting leachate as a nutrient. Biores Technol 190:431-437

Lonappan L, Brar SK, Das RK, Verma M, Surampalli RY (2016) Diclofenac and its transformation products: environmental occurrence and toxicity - a review. Environ Int 96:127-138

Mahdad F, Younesi H, Bahramifar N, Hadavifar M (2016) Optimization of Fenton and photo-Fenton-based advanced oxidation processes for post-treatment of composting leachate of municipal solid waste by an activated sludge process. KSCE J Civ Eng 20(6):2177-2188

Mahvi AH, Feizabadi GK, Dehghani MH, Mazloomi S (2015) Efficiency of different coagulants in pretreatment of composting plant leachate. J Biodivers Environ Sci $6(6): 21-28$

Maleki A, Zazouli MA, Izanloo H, Rezaee R (2009) Composting plant leachate treatment by coagulation-flocculation process. Am-Eurasian J Agric Environ Sci 5(5):638-643

Marttinen SK, Hänninen K, Rintala JA (2004) Removal of DEHP in composting and aeration of sewage sludge. Chemosphere 54(3):265-272

Matilainen A, Sillanpää M (2010) Removal of natural organic matter from drinking water by advanced oxidation processes. Chemosphere 80(4):351-365

Ming L, Xuya P, Youcai Z, Wenchuan D, Huashuai C, Guotao L, Zhengsong W (2008) Microbial inoculum with leachate recirculated cultivation for the enhancement of OFMSW composting. J Hazard Mater 153(1):885-891

Mokhtarani N, Bayatfard A, Mokhtarani B (2012) Full scale performance of compost's leachate treatment by biological anaerobic reactors. Waste Manag Res 30(5):524-529

Mokhtarani N, Nasiri A, Ganjidoust H, Yasrobi SY (2014) Posttreatment of composting leachate by ozonation. Ozone Sci Eng 36(6):540-548

Mokhtarani N, Yasrobi SY, Ganjidoust H (2015) Optimization of ozonation process for a composting leachate-contaminated soils treatment using response surface method. Ozone Sci Eng 37(3):279-286

Mokhtarani N, Khodabakhshi S, Ayati B (2016) Optimization of photocatalytic post-treatment of composting leachate using UV/TiO2. Desalin Water Treat 57(47):22232-22243

Mullane JM, Flury M, Iqbal H, Freeze PM, Hinman C, Cogger CG, Shi Z (2015) Intermittent rainstorms cause pulses of nitrogen, phosphorus, and copper in leachate from compost in bioretention systems. Sci Total Environ 537:294-303

Nissinen TK, Miettinen IT, Martikainen PJ, Vartiainen T (2001) Molecular size distribution of natural organic matter in raw and drinking waters. Chemosphere 45(6):865-873 
Ozkaya B (2005) Chlorophenols in leachates originating from different landfills and aerobic composting plants. J Hazard Mater 124(1-3):107-112

Ozturk I, Altinbas M, Koyuncu I, Arikan O, Gomec-Yangin C (2003) Advanced physico-chemical treatment experiences on young municipal landfill leachates. Waste Manag 23(5):441-446

Popa R, Green TR (2012) Using black soldier fly larvae for processing organic leachates. J Econ Entomol 105(2):374-378

Quinteiro P, Dias AC, Araújo A, Pestana JLT, Ridoutt BG, Arroja L (2015) Suspended solids in freshwater systems: characterisation model describing potential impacts on aquatic biota. Int J Life Cycle Assess 20(9):1232-1242

Rajabi S, Vafajoo L (2012) Investigating the treatability of a compost leachate in a hybrid anaerobic reactor: an experimental study. Int J Environ Chem Ecol Geol Geophys Eng $6(1): 42-45$

Robinson A (2005) Landfill leachate treatment. Membr Technol 2005(6):6-12

Romero C, Ramos P, Costa C, Márquez MC (2013) Raw and digested municipal waste compost leachate as potential fertilizer: comparison with a commercial fertilizer. J Clean Prod 59:73-78

Roy D, Gherrou A, Pierre P, Landry D, Yargeau V (2017) Reverse osmosis applied to soil remediation wastewater: comparison between bench-scale and pilot-scale results. J Water Process Eng 16:115-122

Sanchez-Monedero MA, Stentiford EI, Mondini C (2003) Biofiltration at composting facilities: effectiveness for bioaerosol control. Environ Sci Technol 37(18):4299-4303

Savage AJ, Tyrrel SF (2005) Compost liquor bioremediation using waste materials as biofiltration media. Biores Technol 96(5):557-564

Seyda Özyaka V, Çakmakci M, Yaman FB, Özkaya B, Karadag D (2015) Treatment of compost leachate by membrane processes. Environ Eng Manag J 14(9):2237-2241

Simonič M (2017) Compost leachate treatment using polyaluminium chloride and nanofiltration. Open Chem 15:123

Singh SK, Tang WZ, Tachiev G (2013) Fenton treatment of landfill leachate under different COD loading factors. Waste Manag 33(10):2116-2122

Soubh A, Mokhtarani N (2016) The post treatment of composting leachate with a combination of ozone and persulfate oxidation processes. RSC Adv 6(80):76113-76122

Tabatabaei S-H, Najafi P, Mirzaei SMJ, Nazem Z, Heidarpour M, Hajrasoliha S, Afyuni M, Harchegani HB, Landi E, Akasheh L, Zamanian M, Barani M, Amini H (2012) Compost' leachate recycling through land treatment and application of natural Zeolite. Int J Recycl Organic Waste Agric 1(1):1-7

Tas DO, Karahan Ö, Övez Orhon D, Spanjers H (2009) Biodegradability and denitrification potential of settleable chemical oxygen demand in domestic wastewater. Water Environ Res 81(7):715-727
Thörneby L, Hogland W, Stenis J, Mathiasson L, Somogyi P (2003) Design of a reverse osmosis plant for leachate treatment aiming for safe disposal. Waste Manag Res 21(5):424-435

Tizaoui C, Bouselmi L, Mansouri L, Ghrabi A (2007) Landfill leachate treatment with ozone and ozone/hydrogen peroxide systems. J Hazard Mater 140(1):316-324

Trujillo D, Font X, Sanchez A (2006) Use of Fenton reaction for the treatment of leachate from composting of different wastes. J Hazard Mater 138(1):201-204

Tyrrel SF, Seymour I, Harris JA (2008) Bioremediation of leachate from a green waste composting facility using waste-derived filter media. Biores Technol 99(16):7657-7664

Ulén B (1997) Leaching of plant nutrients and heavy metals during the composting of household wastes and chemical characterization of the final product. Acta Agric Scand Sect B Soil Plant Sci 47(3):142-148

UNEP (2009) Year book 2009 New science and developments in our changing environment, 70

Wang F, Smith DW, El-Din MG (2003) Application of advanced oxidation methods for landfill leachate treatment: a review. J Environ Eng Sci 2(6):413-427

Weng L, Temminghoff EJ, Lofts S, Tipping E, Van Riemsdijk WH (2002) Complexation with dissolved organic matter and solubility control of heavy metals in a sandy soil. Environ Sci Technol 36(22):4804-4810

Xie B, Lv Z, Lv B, Gu Y (2010) Treatment of mature landfill leachate by biofilters and Fenton oxidation. Waste Manag 30(11):2108-2112

Zahrim AY, Asis T, Hashim MA, Al-Mizi TMTMA, Ravindra P (2015) A review on the empty fruit bunch composting: life cycle analysis and the effect of amendment(s). In: Ravindra $P$ (ed) Advances in bioprocess technology. Springer, Cham, pp 3-15

Zazouli M, Yousefi Z (2008) Removal of heavy metals from solid wastes leachates coagulation-flocculation process. J Appl Sci 8(11):2142-2147

Zhang C, Zeng G, Yuan L, Yu J, Li J, Huang G, Xi B, Liu H (2007) Aerobic degradation of bisphenol A by Achromobacter xylosoxidans strain B-16 isolated from compost leachate of municipal solid waste. Chemosphere 68(1):181-190

Zhou C, Wang R, Zhang Y (2010) Fertilizer efficiency and environmental risk of irrigating Impatiens with composting leachate in decentralized solid waste management. Waste Manag 30(6): 1000-1005

Zuriaga-Agustí E, Mendoza-Roca JA, Bes-Piá A, AlonsoMolina JL, Fernández-Giménez E, Álvarez-Requena C, Muñagorri-Mañueco F, Ortiz-Villalobos G (2016) Comparison between mixed liquors of two side-stream membrane bioreactors treating wastewaters from waste management plants with high and low solids anaerobic digestion. Water Res 100:517-525 